\title{
Characterization and Evaluation of the Potential of a Diesel-Degrading Bacterial Consortium Isolated from Fresh Mangrove Sediment
}

\author{
Firmin Semboung Lang • Jacqueline Destain • Frank Delvigne • \\ Philippe Druart • Marc Ongena $\cdot$ Philippe Thonart
}

Received: 9 September 2015 / Accepted: 5 January 2016

(C) Springer International Publishing Switzerland 2016

\begin{abstract}
Hydrocarbons are ubiquitous and persistent organic pollutants in the environment. In wetlands and marine environments, particularly in mangrove ecosystems, their increase and significant accumulation result from human activities such as oil and gas exploration and exploitation operations. Remediation of these ecosystems requires the development of adequate and effective strategies. Natural attenuation, biostimulation, and bioaugmentation are all biological soil treatment techniques that can be adapted to mangroves. Our experiments were performed on samples of fresh mangrove sediments from the Cameroon estuary and mainly from the Wouri River in Cameroon. This study aims to assess the degradation potential of a bacterial consortium isolated from mangrove sediment. The principle of our bioremediation experiments is based on a series of tests designed to evaluate the potential of an active indigenous microflora and three exogenous pure strains, to degrade diesel with/without adding nutrients. The experiments were conducted in laboratory flasks and a greenhouse in microcosms. In one case, as in the other, the endogenous microflora showed that it was able to
\end{abstract}

\footnotetext{
F. S. Lang $(\bowtie) \cdot J$. Destain $\cdot$ F. Delvigne $\cdot$ M. Ongena $\cdot$

P. Thonart

Université de Liège-Gembloux Agro Bio-Tech. Centre Wallon de Biologie Industrielle, Passage des Déportés, 2, B-5030 Gembloux, Belgium

e-mail: langsemb@yahoo.fr

P. Druart

Centre Wallon de Recherche Agronomique (CRA-W), Chaussée de Namur, 24, B-5030 Gembloux, Belgium
}

degrade diesel. Under stress of the pollutant, the endogenous microflora fits well enough in the middle to enable metabolism of the pollutant. However, the Rhodococcus strain was more effective over time. The degradation rate was 77 and $90 \%$ in the vials containing the sterile sediments and non-sterile sediments, respectively. The results are comparable with those obtained in the microcosms in a greenhouse where only the endogenous microflora were used. The results of this study show that mangrove sediment contains an active microflora that can metabolize diesel. Indigenous and active microflora show an interesting potential for diesel degradation.

Keywords Mangrove - Oil pollution · Microorganisms · Bioremediation

\section{Introduction}

Polycyclic aromatic hydrocarbons (PAHs) are ubiquitous and persistent organic pollutants in the environment (Tam and Wong 2008; Lu et al., 2011). In wetlands and marine environments, particularly in mangrove ecosystems, their increase and significant accumulation result from human activities such as oil and gas exploration and exploitation operations. Oil spills occur during tanker-loading operations in the oil platforms or in the ballast tanks of ships, most often near the mainland coast during the transportation of crude oil in pipelines, urban discharges in service stations from petroleum products, emissions from combustion and industrial 
processes (Tam and Wong 2008), etc. Biodegradation of petroleum hydrocarbons is a complex process that depends on the type and on the amount of hydrocarbons. Petroleum hydrocarbons can be divided into four classes: saturates, aromatics, asphaltenes (phenols, fatty acids, ketones, esters, and porphyrins), and resins (pyridines, quinolines, carbazoles, sulfoxides, and amides) (Colwell et al., 1977). Different factors influencing hydrocarbon degradation have been reported by Cooney et al., (1985). One important factor that limits biodegradation of oil pollutants in the environment is their limited availability to microorganisms. Petroleum hydrocarbon compounds bind to soil components, and are consequently removed or degraded with difficulty (Barathi and Vasudevan 2001). Hydrocarbons differ in their susceptibility to microbial attack. The susceptibility of hydrocarbons to microbial degradation can be generally ranked as follows: linear alkanes $>$ branched alkanes $>$ small aromatics $>$ cyclic alkanes (Perry, 1984; Ulrici, 2000). Some compounds, such as the high molecular weight polycyclic aromatic hydrocarbons (PAHs), may not be degraded at all (Atlas and Bragg 2009). Bacteria are the most active agents in petroleum degradation, and they work as primary degraders of spilled oil in the environment (Rahman et al. 2003; Brooijmans et al., 2009). Several bacteria are even known to feed exclusively on hydrocarbons (Yakimov et al., 2007). Floodgate (1984) listed 25 genera of hydrocarbon-degrading bacteria and 25 genera of hydrocarbon-degrading fungi which were isolated from a marine environment. A similar compilation by Bartha and Bossert (1984) included 22 genera of bacteria and 31 genera of fungi. Mangrove ecosystems are plant formations along the coasts of tropical and subtropical regions. They are closely related to industrial activities and are subject to various forms of pollution including oil pollution. Remediation of these ecosystems requires the development of adequate and effective strategies. In addition to the physicochemical treatment of contaminated sites, which is known for its high financial cost, more accessible biological processes also appear adapted to mangrove ecosystems (Singh et al., 2010). Natural attenuation, bioaugmentation, phytoremediation, etc., are all biological soil treatment techniques that can be adapted to mangroves. These techniques use plants and/or microorganisms to degrade hydrocarbons (Tam and Wong 2008). Mangrove sediment contains an abundant and diverse microflora mainly composed of bacteria and fungi. According to
Holguin et al. (2001), bacteria and fungi account for $91 \%$ of the total microbial biomass in tropical mangroves, while algae and protozoa represent only 7 and $2 \%$, respectively. Fungal populations have been found in the rhizosphere of mangroves dominated by Avicennia marina along the coast of Karachi (Mehdi et al. 2000). Leahy and Colwell, (1990) have reported biodegradation of petroleum oil by Achromobacter, Arthrobacter Acinetobacter, Alcaligenes, Bacillus, Flavobacterium, Nocardia, Pseudomonas, and Rhodococcus. The present study, therefore, aims to assess the diesel degradation potential of endogenous microflora and to compare this potential with that of other pure strains known for their ability to degrade diesel.

The bacterial consortium isolated of mangrove sediments is an active bacterial starter product bioreactor. Exogenous strains used are Bacillus subtilis, Pseudomonas fluorescens, and Rhodococcus erythropolis. These strains are known for their ability to degrade hydrocarbons. B. subtilis is a Gram-positive, catalase-positive bacterium commonly found in soil. It produces a natural surfactant, possesses the ability to biodegrade hydrocarbons, and is a facultative aerobe. Spores can survive extreme heat. B. subtilis also produces a biosurfactant, surfactin, in the presence of crude oil. Laboratory experiments have shown that biosurfactant production is not inhibited by the presence of crude oil (Queiroga et al., 2003). Several experiments of bioremediation of soils polluted by hydrocarbons were performed with B. subtilis (Moran et al., 2000; Christova et al., 2004; Das and Mukherjee 2007; Wang et al., 2011; Jalilzadeh Yengejeh et al., 2014; Darsa et al., 2014). The strain P. fluorescens was used in a number of hydrocarbon biodegradation experiments. Chandrasekhar and Karigar (2010) used this strain for the degradation of anthracene. Kaczorek and Olszanowski (2011) used P. fluorescens to evaluate the effects of exogenous biosurfactants on biodegradation of hydrocarbons. The genus Rhodococcus-bacteria with a diverse and efficient metabolism - is also able to transform, biodegrade, or utilize as a carbon source several hydrophobic compounds such as hydrocarbons, chlorinated phenols, steroids, lignin, coal, and crude oil. $R$. erythropolis is an ideal candidate for enhancing the bioremediation of contaminated mangrove sites. Rhodococcus has been proven to be of immense use also for enantioselective synthesis and the production of amides from nitriles. This capability could be of great 
commercial and industrial importance. Rhodococcus are aerobic, Gram-positive, non-motile, nocardioform actinomycetes, with a life cycle alternating between cocci and small rods, sometimes showing small filamentous projections (Bicca et al., 1999). R. erythropolis has the ability to occupy many niches; this species dominates the nitrile-degrading microorganisms from many marine and terrestrial zones (Brandao et al., 2003). Diesel oil is an excellent model for studying hydrocarbon biodegradation, since it is constituted of a variety of these molecules, such as paraffin, olefins, naphtha, and aromatic compounds. The molecular weight of the hydrocarbons in diesel is also variable, with molecules containing 9 to 20 carbon atoms.

\section{Materials and Methods}

\subsection{Soil and Diesel}

The experiment was performed on samples of fresh mangrove sediments from the Cameroon estuary, mainly from the Wouri River in Cameroon. The physicochemical characteristics of the soil samples were determined. The diesel used in this study was commercial diesel; it contained $75.2 \%$ of aliphatic hydrocarbons, carbon chains are $\mathrm{C}_{11}$ to $\mathrm{C}_{24}$ and $24.7 \%$ aromatic hydrocarbons.

\subsection{Development of the Consortium Bacterial Starter}

Our initial bacterial consortium was isolated from fresh mangrove sediment. $250 \mathrm{~g}$ of fresh sediment were lyophilized for $72 \mathrm{~h}$. One gram of lyophilized sediment was introduced into a test tube containing $9 \mathrm{~mL}$ of sterile peptone water. The test tube containing the mixture was placed in a water bath at $80^{\circ} \mathrm{C}$ for $15 \mathrm{~min}$. This process allowed us to obtain a competent microflora resistant to heat shocks. Dilutions were carried out by plating the extracts on a mineral salt medium (MSM) with $10 \mathrm{ppm}$ of diesel as the sole carbon source and solidified with agar in Petri dishes. Each dilution was spread three times. After 3 days of incubation at $30{ }^{\circ} \mathrm{C}$, the number of CFUs (colony forming units) was counted and the mean of each dilution was raised. MSM had the following composition $(\mathrm{mg} / \mathrm{L})$ : $\left(\mathrm{NH}_{4}\right)_{2} \mathrm{SO}_{4}, 1000 ; \mathrm{K}_{2} \mathrm{HPO}_{4}$, $800 ; \mathrm{KH}_{2} \mathrm{PO}_{4}, 200 ; \mathrm{MgSO}_{4} .7 \mathrm{H}_{2} \mathrm{O}, 200 ; \mathrm{CaCl}_{2} .2 \mathrm{H}_{2} \mathrm{O}$, 100 ; and trace elements $\left(\mathrm{FeSO}_{4} .7 \mathrm{H}_{2} \mathrm{O}, 12\right.$; $\mathrm{MnSO}_{4} .7 \mathrm{H}_{2} \mathrm{O}, 3 ; \mathrm{ZnSO}_{4} .7 \mathrm{H}_{2} \mathrm{O}, 3 ; \mathrm{CoSO}_{4} .7 \mathrm{H}_{2} \mathrm{O}, 1$; and $\left.\left(\mathrm{NH}_{4}\right)_{6} \mathrm{Mo}_{7} \mathrm{O}_{24} \cdot 4 \mathrm{H}_{2} \mathrm{O}, 1\right) ; 15 \mathrm{~g}$ agar. The medium $\mathrm{pH}$ was 7.0-7.2. MSM was prepared in deionized water except when salinity effects were examined when artificial seawater at $10 \mathrm{~g} / \mathrm{L}$ salinity was used to dissolve various salts. To obtain the total microflora, we used rich medium (glucose, $20 \mathrm{~g} / \mathrm{L}$; peptone, $10 \mathrm{~g} / \mathrm{L}$; yeast extract, $10 \mathrm{~g} / \mathrm{L}$; Tween $80,1 \mathrm{~mL} / \mathrm{L})$. For cultures on solid medium (enumeration and recovery of data stored on microbeads strains), this medium was supplemented with $15 \mathrm{~g} / \mathrm{L}$ of agar.

We used a bioreactor for the production of bacterial biomass. The fermentation process led to the creation of a pre-culture reactor for carrying out the culture itself. Data were collected at each step and the results analyzed. The pre-cultures were carried out with the rich medium with $10 \mathrm{~mL} / \mathrm{L}$ of diesel added. Bacterial growth was monitored by measuring optical density $(\lambda=600 \mathrm{~nm})$ over a 48 -h period. The pre-cultures were performed as follows: $1 \mathrm{~mL}$ of suspension equivalent to $10^{4} \mathrm{CFUs} / \mathrm{mL}$ of bacterial spores was added into a 250 $\mathrm{mL}$ flask containing $100 \mathrm{~mL}$ of rich medium autoclaved for $20 \mathrm{~min}$ at $121^{\circ} \mathrm{C}$ and $10 \mathrm{~mL} / \mathrm{L}$ of diesel. The flask was brought to the oven at $30^{\circ} \mathrm{C}$ on a stirring plate. The evolution of biomass in the flask was monitored for $48 \mathrm{~h}$ until it reached $10^{7} \mathrm{CFUs} / \mathrm{mL}$. This was pre-culture 1 . Pre-culture 1 inoculum was used for pre-culture 2, which was carried out in a $2-\mathrm{L}$ flask containing $500 \mathrm{~mL}$ of rich medium and $10 \mathrm{~mL} / \mathrm{L}$ of sterile diesel, and incubated at $30{ }^{\circ} \mathrm{C}$ under stirring for $24 \mathrm{~h}$.

A 20-L bioreactor (BIOLAFITTE, $\mathrm{N}^{\circ} \mathrm{C} 38304$, France) was used for biomass production. An equivalent volume of $16 \mathrm{~L}$ of rich medium supplemented with diesel was introduced into the bioreactor for sterilization. After cooling, the inoculum (pre-culture 2) was added to the mixture. Once the bioreactor was launched, successive counts were conducted for $48 \mathrm{~h}$. At the end of the process, the suspension was recovered and then centrifuged. The biomass obtained was stored at $-20{ }^{\circ} \mathrm{C}$ for $24 \mathrm{~h}$ before lyophilization. Two percent $(v / v)$ glycerol and $10 \%(v / v)$ maltodextrin were added as cryoprotectants to limit the effects of lyophilization on bacteria. Bioreactor conditions were as follows: temperature, $30{ }^{\circ} \mathrm{C}$; $\mathrm{pH}, 6.5$ to 7 ; aeration, $0.5 \mathrm{vvm}$; shaking, $130 \mathrm{rpm}$; and duration, $48 \mathrm{~h}$. Centrifugation (Thermo Scientific ${ }^{\circledR}$ SORVALL RC12BP TM, France) conditions were as follows: temperature, $\pm 4{ }^{\circ} \mathrm{C}$; shaking, $4700 \mathrm{rpm}$; and time, $15 \mathrm{~min}$.

After $24 \mathrm{~h}$ at $-20^{\circ} \mathrm{C}$, the biomass was lyophilized for $72 \mathrm{~h}$ to obtain a powder. Shelf temperature was adjusted 
between -40 and $+50{ }^{\circ} \mathrm{C}$. The trap reached a temperature below $-50{ }^{\circ} \mathrm{C}$ at the end of the lyophilization process. A count was made after lyophilization to assess the performance after that step. The bacterial starter was used throughout this study as diesel-degrading biomass.

\subsection{Biodegradation Experiments}

The characterization of active bacterial consortium isolated in mangrove sediments was performed through two different experiments. The first was conducted in flask. Only the active consortium was tested on artificially contaminated sediments by diesel. The second experiment was done in a greenhouse in microcosms with larger volumes of sediment. For this last experiment, the diesel degradation potential of the endogenous microflora was compared with that of exogenous pure strains known for their ability to degrade hydrocarbons.

\subsubsection{In Flasks}

For this experimentation, this study aimed to assess the degradation potential of a bacterial consortium isolated from mangrove sediment. The biodegradation assays took place using two techniques with several series, and different treatments in the flasks. Each series was performed in triplicate. The experiment was conducted as follows: the first technique was performed with sterile mangrove sediments and the second used non-sterile mangrove sediments. For the first technique, we achieved the experiment with two series of three flasks. In one series, $100 \mathrm{~g}$ of mangrove sediments was introduced. The flasks were sterilized by autoclaving. Then, $1 \mathrm{~mL} / \mathrm{L}$ of diesel $(10,000 \mathrm{ppm})$ was added. We also inoculated a $10^{7} \mathrm{CFU} / \mathrm{g}$ consortium as a starter and $250 \mathrm{~mL}$ of artificial seawater. The second series of flasks was treated as above with the only difference being the addition of $30 \%$ nutrient solution. For the second technique, the experiment was carried out in four series of three flasks with non-sterile sediment. In the first series of flasks, $100 \mathrm{~g}$ of mangrove sediment was introduced and $250 \mathrm{~mL}$ of artificial seawater was added; this was the treatment by natural attenuation. The second series concerned treatment by biostimulation, and involved the above treatment followed by the addition of $30 \%$ nutrient solution. The third series was the same as the first, followed by inoculation with $10^{7} \mathrm{CFU} / \mathrm{g}$ bacterial consortium powder; this was the bioaugmentation. The fourth series was treated as the third, with the addition of $30 \%$ nutrient solution; this was the combination of biostimulation and bioaugmentation. A series of three flasks containing $500 \mathrm{~g}$ of sterile mangrove sediment and $250 \mathrm{~mL}$ of artificial seawater without the addition of microorganisms was the control flask for this experiment. Figure 1 summarizes the experiment set up applied to the study of biodegradation in flasks.

\subsubsection{Biodegradation in Greenhouse}

This used three different traditional techniques for the biological treatment of polluted soils. These techniques are: natural attenuation, biostimulation, bioaugmentation and a combination of bioaugmentation and biostimulation. Regarding natural attenuation, $500 \mathrm{~g}$ of mangrove sediments polluted with previously diesel $(10,000 \mathrm{ppm})$ was introduced into a series of three microcosms; then, $750 \mathrm{~mL}$ of artificial sea water was introduced into each of three microcosms so that the sediments were fully immersed in water. The artificial seawater had the following composition in one liter of MilliQ water (g/L): $\mathrm{NaCl}, 10 ; \mathrm{KCl}, 0.74 ; \mathrm{CaCl}_{2}, 0.99$; $\mathrm{MgCl}_{2}, 6.09 ; \mathrm{MgSO}_{4}, 3.94$; and $\mathrm{pH}, 7.8$ (pH was adjusted with $\mathrm{NaOH}$ to increase or $\mathrm{HCl}$ to decrease) and the liter bottle was sterilized by autoclave. The three microcosms corresponded to three repetitions. Regarding the bioaugmentation, four series were treated
Fig. 1 Biodegradation experiment in flasks

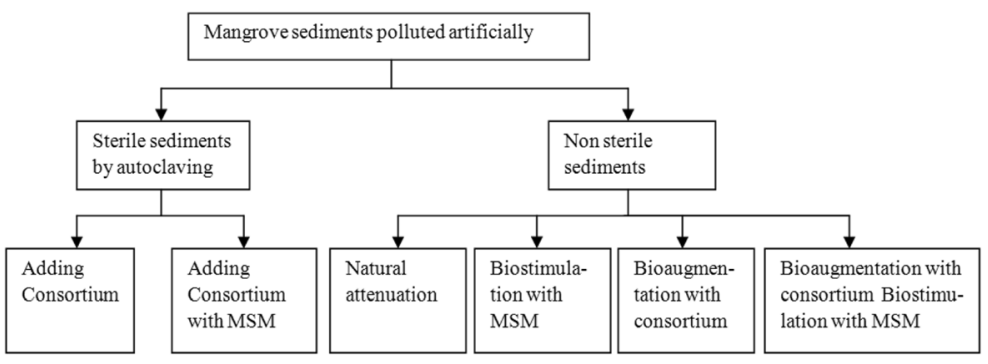


as previous microcosms; in the first series, a bacterial consortium isolated from mangrove sediments was added; in the second series, a pure culture of $R$. erythropolis was used, in the third series, a pure culture of $B$. subtilis was added and in the fourth series, P. fluorescens was added. Regarding biostimulation, two concepts were tried: stimulating endogenous microorganisms with a mineral salt medium (MSM) and organic material in the form of compost, or both. In this case, $500 \mathrm{~g}$ of polluted mangrove sediment was introduced into three series of three microcosms. In the first series, $30 \%$ MSM was added, while in the other, $30 \%$ of compost was added. In the third series, $30 \% \mathrm{MSM}$ and $30 \%$ compost was added to both. The second concept is the combination of the bioaugmentation and biostimulation. In this case, two series of microcosms were treated as described above under bioaugmentation. Here, $30 \%$ MSM was added in one series and the other contained $30 \%$ compost. MSM had the following composition $(\mathrm{mg} / \mathrm{L})$ : $\left(\mathrm{NH}_{4}\right)_{2} \mathrm{SO}_{4}, 1000 ; \mathrm{K}_{2} \mathrm{HPO}_{4}, 800$; $\mathrm{KH}_{2} \mathrm{PO}_{4}, 200 ; \mathrm{MgSO}_{4} .7 \mathrm{H}_{2} \mathrm{O}, 200 ; \mathrm{CaCl}_{2} .2 \mathrm{H}_{2} \mathrm{O}, 100$; and trace elements made up of $\mathrm{FeSO}_{4} .7 \mathrm{H}_{2} \mathrm{O}, 12$; $\mathrm{MnSO}_{4} .7 \mathrm{H}_{2} \mathrm{O}, 3 ; \mathrm{ZnSO}_{4} .7 \mathrm{H}_{2} \mathrm{O}, 3 ; \mathrm{CoSO}_{4} .7 \mathrm{H}_{2} \mathrm{O}, 1$; and $\left(\mathrm{NH}_{4}\right)_{6} \mathrm{Mo}_{7} \mathrm{O}_{24} \cdot 4 \mathrm{H}_{2} \mathrm{O}, 1$. Compost had the following physicochemical composition: $25 \%$ white peat; $30 \%$ Baltic black peat; $45 \%$ German black peat with $1.5 \mathrm{~kg}$ of PG mix NPK fertilizer $(14+16+18+$ trace elements); $\mathrm{pH}, 6$.

Two additional mixtures were developed to serve as controls; this was formed by the first four series of three microcosms containing $500 \mathrm{~g}$ each of sterile mangrove sediment polluted with diesel (10,000 ppm) and $750 \mathrm{~mL}$ of artificial seawater. In the first one, a bacterial consortium was added; in the second one, a pure strain of $R$. erythropolis was used; B. subtilis was added into the third one; and P. fluorescens was used in the fourth one. The second installation was performed by a single series of microcosms containing $500 \mathrm{~g}$ of sterile mangrove sediment artificially contaminated with diesel (10,000 ppm); this series did not contain microorganisms. The experiment lasted for 5 weeks. The water and soil samples were taken once a week to measure the total petroleum hydrocarbon (TPH). Figure 2 summarizes the experiment set up applied to the study of biodegradation in the greenhouse.

\subsection{Cytometric Assays}

Accuri CFlow ${ }^{\circledR}$ or CFlow Plus software (CFlow) was used to control the C6 Flow Cytometer ${ }^{\circledR}$ system, acquire data, generate statistics, and analyze results. CFlow software provides the following features: tabbed views for collection, analysis, and statistics. Cytometric analyses were aimed at characterizing the consortium under diesel stress quantitatively and qualitatively. All bacteria in the consortium did not react in the same way to diesel stress; therefore, we studied parameters such as viability and membrane integrity by labeling them with propidium iodide $(\mathrm{PI})$, an intercalating agent. The amount of PI determined for each cell was proportional

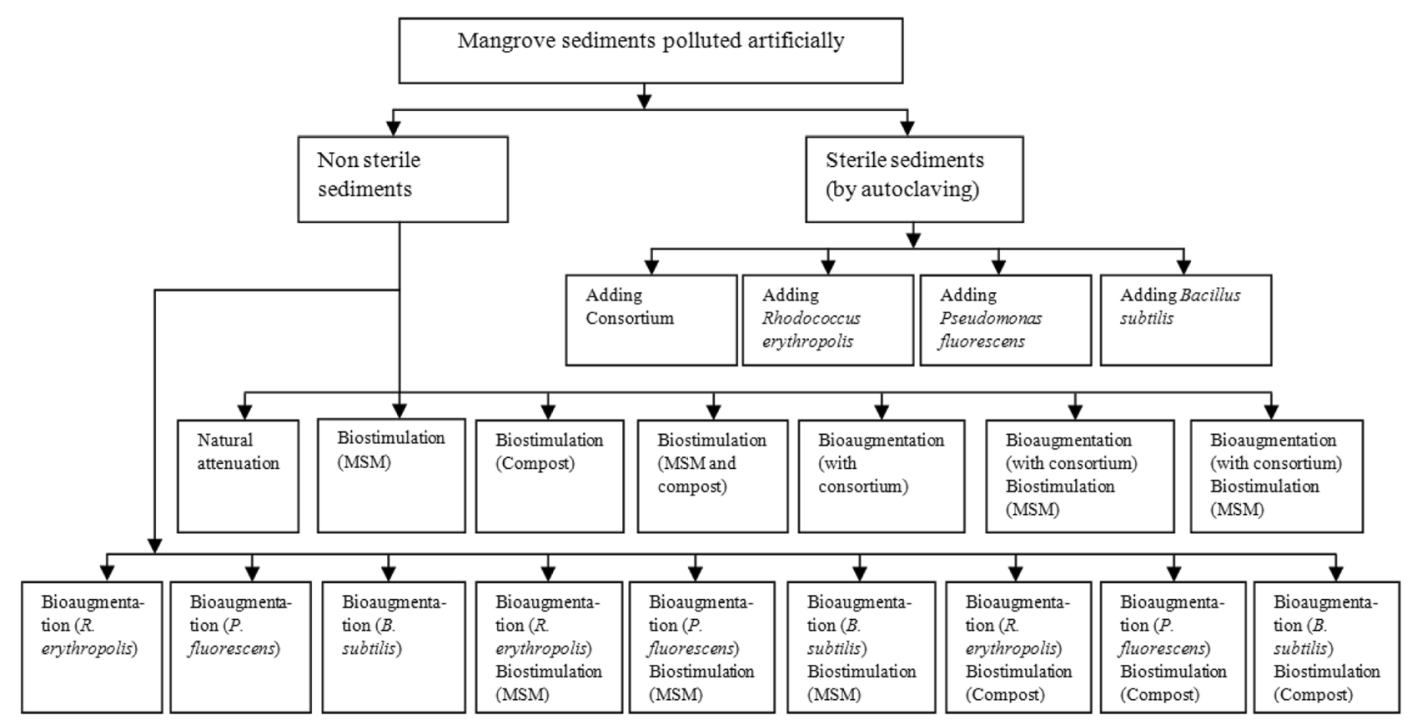

Fig. 2 Biodegradation experiment in the greenhouse 
to the DNA content. PI allowed us to assess the membrane integrity of the cells. We also used cFDA (carboxyfluorescein diacetate), another intercalating agent, to assess bacterial mortality during the experiment. The analysis was performed every two days throughout the entire experiment.

Cytometric analysis first requires the extraction of soil bacteria. Extraction was performed as follows: $10 \mathrm{~mL}$ of mangrove sludge was placed in a $50 \mathrm{~mL}$ Falcon ${ }^{\circledR}$ tube, and then $10 \mathrm{~mL}$ of PBS $(\times 10)$ containing $0.1 \%$ sodium pyrophosphate plus $0.05 \%$ Tween 20 was added. The tubes were vortexed and placed on a rotary stirrer for $30 \mathrm{~min}$ and then centrifuged for $10 \mathrm{~min}$ at $500 \mathrm{rpm}$. After centrifugation, $1 \mathrm{~mL}$ of supernatant was transferred into a microtube, and $1 \mathrm{~mL}$ of Nycodenz solution, density 1.3 ( $8 \mathrm{~g}$ Nycodenz powder in $10 \mathrm{~mL}$ of distilled $\mathrm{H}_{2} \mathrm{O}$ ), was added. The mixture was centrifuged for $10 \mathrm{~min}$ at $10,000 \mathrm{rpm}$. As a result, three layers became visible in the microtubes: a precipitate at the bottom, ground water in the middle, and a bacterial layer on the top. The bacterial layer was recovered.

One milliliter of the bacterial layer was transferred into two microtubes: the first was heated at $90{ }^{\circ} \mathrm{C}$ for $30 \mathrm{~min}$ in a water bath (heat shock) and the second was placed on ice (reference sample). For each sample, $100 \mu \mathrm{L}$ of the bacterial layer was introduced into another microtube, and then $900 \mu \mathrm{L}$ of PBS $(0.2 \mu \mathrm{m}$ filtered $)$ and $10 \mu \mathrm{L}$ of PI and CFDA were added. The mixture was vortexed, incubated at $37{ }^{\circ} \mathrm{C}$ for $15 \mathrm{~min}$ and then centrifuged at 10,000 rpm for $2 \mathrm{~min}$. The pellet (desired range $10^{6} \mathrm{CFUs} / \mathrm{mL}$ ) was recovered, $1000 \mu \mathrm{L}$ of PBS were added, and the cells were resuspended using a vortex before cytometry analysis.

PBS (1× solution) was composed of $800 \mathrm{~mL}$ of distilled $\mathrm{H}_{2} \mathrm{O} ; 8 \mathrm{~g}$ of $\mathrm{NaCl} ; 0.2 \mathrm{~g}$ of $\mathrm{KCl} ; 1.44 \mathrm{~g}$ of $\mathrm{Na}_{2} \mathrm{HPO}_{4}$; and $0.24 \mathrm{~g}$ of $\mathrm{KH}_{2} \mathrm{PO}_{4}$. The $\mathrm{pH}$ was adjusted to 7.4 with $\mathrm{HCl}$. The final volume was adjusted to $1 \mathrm{~L}$ with additional distilled $\mathrm{H}_{2} \mathrm{O}$, and the preparation was sterilized by autoclaving.

\subsection{Total Petroleum Hydrocarbon (TPH) Analysis and Rate of Diesel Reduction}

Hydrocarbons were extracted using a Soxhlet device. For extraction from sediment, $8 \mathrm{~g}$ of contaminated soil were taken from each flask and were introduced into an extraction thimble (Whatman). The extraction thimbles were then placed in the Soxhlet device. Each balloon contained $70 \mathrm{~mL}$ of acetonitrile saturated with hexane.
Extraction time was $6 \mathrm{~h}$. After the extraction step, the balloons containing about $70 \mathrm{~mL}$ of acetonitrile mixed with hydrocarbons were recovered. An equivalent volume of hexane solution saturated with acetonitrile was added to each balloon. The mix was stirred for $10 \mathrm{~min}$ and yielded two phases: the hexane phase (above) containing hydrocarbons and impurities, the acetonitrile phase (below). $1.5 \mathrm{~g}$ of Florisil (15\% MgO, $85 \%$ $\mathrm{SiO}_{2}$, MACHEREY-NAGEL $\mathrm{GmbH}$ and Co.KG, Germany) and $1.5 \mathrm{~g}$ of sodium sulfate $\left(\mathrm{Na}_{2} \mathrm{SO}_{4}\right)$ were placed in a settling leg made of sintered glass. The two products were designed to retain impurities $\left(\mathrm{Na}_{2} \mathrm{SO}_{4}\right)$ and water (Florisil). The acetonitrile phase (below) was recovered first. The hexane phase containing hydrocarbons of interest was next recovered in another balloon. The balloons containing the hexane phase were then dried and heated in an oven at $105{ }^{\circ} \mathrm{C}$ for $3 \mathrm{~h}$ and then cooled in a desiccator to dry them and protect them from moisture. The solution in each flask was then evaporated using a rotary evaporator heated at $50{ }^{\circ} \mathrm{C}$ to a volume of about $2 \mathrm{~mL}$. The final sample volume was measured and an aliquot was introduced into a vial stored at $4{ }^{\circ} \mathrm{C}$ before GC injection. The remaining diesel oil was quantified by weight to determine the amount of diesel oil degraded over time. The percentage of diesel oil degradation was determined using the amount of diesel oil in the same flask at day 0 as $100 \%$. The dosage of hydrocarbons in soils and water was performed using a gas chromatograph (HP 5890 Series II Gas Chromatograph). Prior external calibration was made with standard diesel (diesel oil additives without DIN H53) and mineral oil (mineral oil additives without DIN H53). Analysis conditions and the characteristics of the column were as follows: pre-column, deactivated fused silica; column Macherey-Nagel Optima 1 (99 \% polydimethylsiloxane, $1 \%$ diphenyl); column length, $30 \mathrm{~m}$; internal diameter of column, $250 \mu \mathrm{m}$; stationary phase thickness, $0.25 \mu \mathrm{m}$; injection volume, $1 \mu \mathrm{L}$; injector, on-column; carrier gas, helium at 0.8 bar; hydrogen fueling the detector, 1.15 bar; FID detector at $300{ }^{\circ} \mathrm{C}$; and oven temperature, $40^{\circ} \mathrm{C}$ for $5 \mathrm{~min}$, temperature rise for $26 \mathrm{~min}$ at a rate of $10{ }^{\circ} \mathrm{C} / \mathrm{min}, 300{ }^{\circ} \mathrm{C}$ for 30 min. Oil content was measured by determining the total petroleum hydrocarbons (TPH) that represents the hydrocarbon concentration calculated from a calibration line. The integrated surface was inbetween the peaks of decane and tetracontane injected extemporaneously dissolved in hexane to determine their retention times. 


\subsection{Quality Control and Statistical Analyses}

Mean values were compared with the ANOVA test with a $p$ value $\leq 0.05$. The differences in the various rates of diesel reduction were also analyzed by the same test. An analysis of variance (ANOVA) was performed to test the differences between initial and final TPH concentrations between the treated flasks and the control flasks. All statistical analyses were performed using MINITAB 15 statistical software (French version).

\section{Results and Discussion}

\subsection{Sediment Characteristics}

The properties of the sediment collected from Wouri mangrove swamps are summarized in Table 1. Wouri sediment contained a lot of sand $(90.6 \%)$ and very little clay $(6.1 \%)$, silt $(3.4 \%)$ or humus $(2 \%)$. It had low levels of organic matter comparable to those observed in the literature and could have a particular affinity with respect to hydrocarbons (Zhang et al., 2007). Similarly, the hydrocarbon and heavy metal levels were low compared to those found in the literature. This could make hydrocarbon degradation complex, because not only are there heavy or persistent petroleum products, but they also settle to the bottom of the water, leading to a nonnegligible fraction of light (or non-persistent hydrocarbons mixes) with fine sand particles in emulsion (Owens et al., 1998). The high concentrations in heavy metals may have a negative effect on activity and microbial density (Ellis et al., 2003). This may result in a reduction of the rate of hydrocarbon degradation by microorganisms, and thereby lead to their accumulation in the soil. Indeed, high concentrations in heavy metals cause a decrease in the microbial biomass, inhibiting some enzymatic activities. A modification of the structure of the microbial community can also be observed (Khan and Scullion 2002). At low concentrations, heavy metals are not supposed to have an effect on the biodegradation process. Here, the concentrations are too low to cause such negative effects. The rapid degradation of hydrocarbons is favored by a number of weather conditions like wind and high temperatures, which accelerate pollutant evaporation. This is not always possible for the pollutants that settle to the bottom of the water. According to Owens et al. (1998), at temperatures ranging between $0{ }^{\circ} \mathrm{C}$ and $5{ }^{\circ} \mathrm{C}, 5$ to $20 \%$ of diesel evaporates in 2 days. The same quantity evaporates in 5 days at temperatures ranging between $-20^{\circ} \mathrm{C}$ and $0{ }^{\circ} \mathrm{C}$.

\subsection{Counting of Bacteria in Sediment}

Different counts from mangrove sediment determined the total microflora and the competent or active (dieseldegrading) microflora. The total microflora obtained from the rich medium containing glucose was $10^{8} \mathrm{CFU} / \mathrm{g}$. The specific competent flora was obtained by subjecting the total microflora to various stresses. When counts from fresh sediment were carried out on a mineral salt medium (MSM) containing $10 \mathrm{ppm}$ diesel as the sole carbon source, the competent microflora count was $1.5 \times 10^{7} \mathrm{CFU} / \mathrm{g}$ soil. After sediment lyophilization, and counting on the same medium, we obtained a microflora count of $8 \times 10^{6} \mathrm{CFU} / \mathrm{g}$ of soil. Finally,

Table 1 Physicochemical properties of the sediments from the Wouri mangroves

\begin{tabular}{|c|c|c|c|c|c|}
\hline Clay & $6.1 \% / \mathrm{DM}$ & \multicolumn{2}{|c|}{ Traces elements (mg/kg dry matter) } & Dry matter (DM) & $80.7 \%$ \\
\hline Silt & $3.4 \% / \mathrm{DM}$ & $\mathrm{Pb}$ & $4 \mathrm{mg} / \mathrm{kg}$ & Conductivity $\left(\mu \mathrm{S} / \mathrm{cm}\right.$ at $\left.20^{\circ} \mathrm{C}\right)$ & 59.2 \\
\hline Sand & $90.6 \% / \mathrm{DM}$ & $\mathrm{Cd}$ & $0.03 \mathrm{mg} / \mathrm{kg}$ & MAH's (mg/kg DM) & $<0.06$ \\
\hline Crude humus & $2 \% / \mathrm{DM}$ & $\mathrm{Cu}$ & $7.7 \mathrm{mg} / \mathrm{kg}$ & Halogen solvents (mg/kg DM) & $<0.2$ \\
\hline Carbon & $1 \% / \mathrm{DM}$ & $\mathrm{Ni}$ & $4 \mathrm{mg} / \mathrm{kg}$ & PAH’s (mg/kg DM) & \\
\hline $\mathrm{pH}(\mathrm{KCl})$ & 6.4 & $\mathrm{Zn}$ & $19.8 \mathrm{mg} / \mathrm{kg}$ & *Mixing Borneff & $<0.07$ \\
\hline \multicolumn{2}{|c|}{ Available elements (mg/100 g) } & $\mathrm{Cr}$ & $28.2 \mathrm{mg} / \mathrm{kg}$ & *Total & $<0.18$ \\
\hline Phosphorus & 3 & As & $1.15 \mathrm{mg} / \mathrm{kg}$ & Total petroleum hydrocarbon (mg/kg DM) & $<100$ \\
\hline Potassium & 4 & $\mathrm{Hg}$ & $0.02 \mathrm{mg} / \mathrm{kg}$ & $\mathrm{C}_{9}-\mathrm{C}_{40}(\mathrm{mg} / \mathrm{kg} \mathrm{DM})$ & 3.28 \\
\hline Magnesium & 23 & Co & $2.9 \mathrm{mg} / \mathrm{kg}$ & PCB's (mg/kg DM) & 0.015 \\
\hline Calcium & 89 & $\mathrm{CN}^{-}$ & $<0.01 \mathrm{mg} / \mathrm{kg}$ & Pesticides chlorinated (mg/kg DM) & $<0.02$ \\
\hline Sodium & 12 & $\mathrm{~F}^{-}$ & $41.4 \mathrm{mg} / \mathrm{kg}$ & & \\
\hline
\end{tabular}


in addition to lyophilization, we placed diluted sediment grown in the same medium for $15 \mathrm{~min}$ in a water bath at $80{ }^{\circ} \mathrm{C}$ and obtained a specific flora of $9 \times 10^{5} \mathrm{CFU} / \mathrm{mg}$ (Fig. 3).

The total microflora and hydrocarbon-degrading microflora fraction may vary among mangroves and depend on weather conditions, the degree of pollution and the sampling place. In a study on the potential for hydrocarbon biodegradation, Tian et al., (2008) counted bacteria from five mangrove sediment samples taken from various locations; they recovered a total of $10^{9}$ cells/g sediment, and between $10^{2}$ and $10^{4}$ hydrocarbon-degrading bacteria/g sediment. Moreira et al. (2011) counted between $10^{5}-10^{7} \mathrm{CFU} / \mathrm{g}$ in Rhizophora mangle rhizosphere and $10^{5}$ to $10^{6} \mathrm{CFU} / \mathrm{g}$ in the non-rhizospheric area. Bacterial activity plays an important role in biomass formation. In tropical mangroves, bacteria and fungi constitute $91 \%$ of the total microbial biomass, whereas algae and protozoa represent only 7 and $2 \%$, respectively (Alongi, 1988; Tian et al., 2008). The unique features of mangroves, i.e., their high primary productivity, abundant detritus, rich organic carbon, and anoxic/reduced conditions make them a preferential site for uptake and preservation of anthropogenic PAHs (Bernard et al., 1996; Tian et al., 2008). Ramsay et al., (2000) report that the number of aromatic-degraders in mangrove sediment is very high $\left(10^{4}-10^{6}\right.$ cells/g sediment), and such an indigenous community has a considerable potential for oil component degradation. Moreover, the number of oildegraders could be increased by oil addition. Yu et al. (2005) also reported that a bacterial consortium enriched from mangrove sediment had a good PAH degradation capability, with $100 \%$ degradation of fluorene and phenanthrene after 4 weeks of growth. These results suggest that mangrove sediment might harbor different groups of hydrocarbon-degrading bacteria.

\subsection{Consortium Production in Bioreactor}

From the competent microflora obtained after a heat shock, we tried to obtain a bacterial starter after the production in bioreactor. The results of the fermentation experiment are shown in Table 2.

The results presented in Table 2 show a good development of competent microflora under the conditions of the bioreactor $1.4 \times 10^{10} \mathrm{CFU} / \mathrm{mL}$. After centrifugation, the culture showed a survival rate of $75.9 \%$. However, the survival rate after lyophilization is only $20 \%$. Cold stress consequently damages the consortium, which comes from tropical areas where the annual average temperature is $23-24^{\circ} \mathrm{C}$.

\subsection{Biodegradation of Diesel in Mangrove Sediment by Bacterial Consortium in Flasks}

The principle of our bioremediation experiment is based on a series of tests designed to assess the potential of an active indigenous microflora to degrade diesel with or without the addition of a nutrient solution. This principle is similar to well-known techniques such as bioaugmentation, biostimulation, and natural attenuation. In this experiment, the mangrove sediment initially had low levels of oil pollution. The addition of diesel increased the TPH to $14,900 \mathrm{ppm}$. After the treatment described above, the dosage of hydrocarbons by GC once per week for 5 weeks showed time-dependent diesel degradation. Degradation was evidenced by the general shape
Fig. 3 Total microflora and active microflora in the mangrove sediment

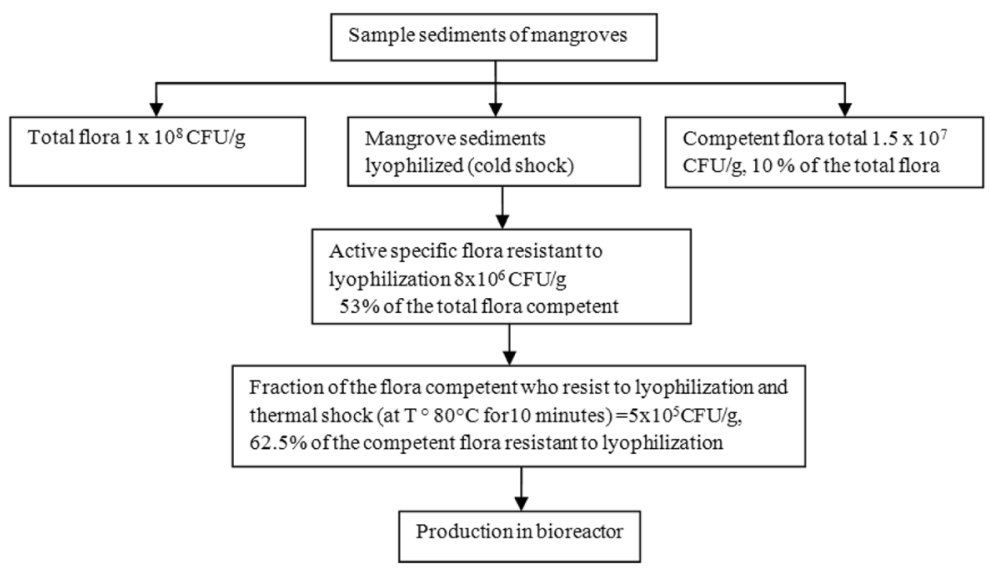


Table 2 Production of consortium in bioreactor

\begin{tabular}{|c|c|c|c|c|c|c|}
\hline \multirow[t]{2}{*}{ Components } & \multicolumn{2}{|c|}{ Periods } & \multicolumn{2}{|c|}{ Number of $\mathrm{CFU} / \mathrm{mL}$ or $\mathrm{CFU} / \mathrm{g}$} & \multirow[t]{2}{*}{ Total CFU } & \multirow[t]{2}{*}{ Yield per step } \\
\hline & Start & End & Start & End & & \\
\hline Volume (L) & $16 \mathrm{~L}$ & $15.7 \mathrm{~L}$ & $8 \times 10^{7}$ & $1.4 \times 10^{10}$ & $2.2 \times 10^{14}$ & \\
\hline Centrifugation & & $458 \mathrm{~g}$ & & $3.7 \times 10^{11}$ & $1.7 \times 10^{14}$ & $75.9 \%$ \\
\hline Lyophilization & & $120 \mathrm{~g}$ & & $3 \times 10^{11}$ & $4.4 \times 10^{13}$ & $20.2 \%$ \\
\hline
\end{tabular}

of the different curves. In flasks initially containing sterile sediment, TPH decreased from 14,900 ppm to 6900-1500 ppm depending on the treatments. To interpret these results, we first had to distinguish between treatments with sterile sediment and those with nonsterile sediment, and then establish the correlation between the two.

In the control flasks without bacteria, no diesel degradation was observed. The rate of diesel reduction in the flasks containing sterile sediment with only consortium added was $68.4 \pm 0.4 \%$ after 5 weeks of treatment, while for sterile sediment that received the consortium and a nutrient solution (containing inorganic nitrates - see "Biodegradation in Greenhouse") a reduction rate of $90.2 \pm 0.2 \%$ was seen within the same time interval (Fig. 4). Nutrients have the particularity of boosting microbial activity. According to one-way ANOVA, statistical analysis (95\% confidence interval) showed no significant difference between the two treatments. However, regardless of the treatment applied, degradation rates are different from one week to the next. The results show a significant difference between the fifth week and the first 4 weeks. The results of the first 2 weeks

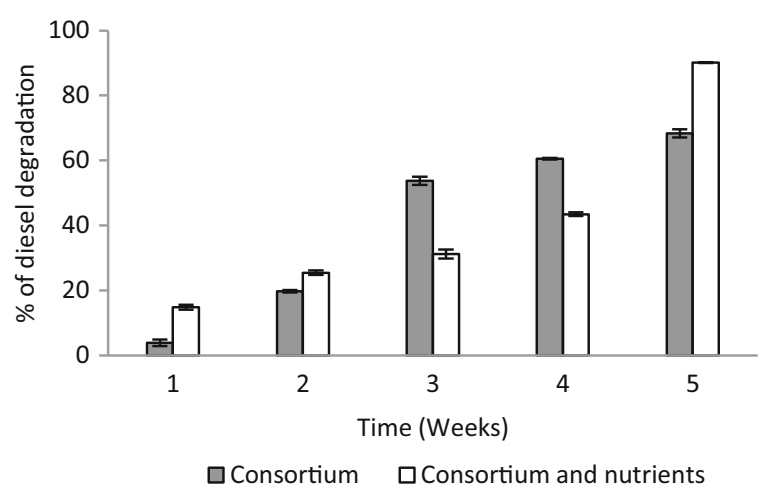

Fig. 4 Percentage of diesel degradation in mangrove sterile sediments using bacterial consortium were significantly different from the following 2 weeks.

With non-sterile sediments, the rate of diesel reduction varied between $54.1 \pm 0.6$ and $77.2 \pm 0.2 \%$. Microbial activity was more intense $(77.2 \pm 0.2 \%)$ in the flasks with only consortium added (bioaugmentation); it was lower $(54.1 \pm 0.6 \%)$ in the consortium-free flasks (natural attenuation). Conversely, we found no difference between the flasks with consortium and nutrient solution added (biostimulation and bioaugmentation) on the one hand and the flasks with only nutrient solution added (biostimulation) on the other. The abatement rate of diesel in these flasks was $67.9 \pm 0.4$ and $67.3 \pm 0.4 \%$, respectively. The results analyzed according to the time and treatment applied show a significant difference between the diesel reduction rate of week 5 and that of the other weeks. Similarly, the abatement rate for weeks 3 and 4 was significantly different from that of the first 2 weeks. Statistical analysis shows that, based on abatement rate, there was no significant difference between treatment with bioaugmentation and biostimulation. In contrast, there was a significant difference in the reduction rate between biostimulation and bioaugmentation treatments and other treatments (Fig. 5).

Our results show that the consortium used has the potential to degrade hydrocarbons. This confirms several previous studies showing that mangroves have indigenous microorganisms capable of metabolizing hydrocarbons (Tam et al., 2002; Yu et al., 2005; Brito et al., 2006; Tam and Wong 2008; Lu et al., 2011; Moreira et al., 2011). In sterile sediment, the consortium used diesel as the sole source of carbon or energy. In the first case, adding nutrient solution in some vials boosted bacterial activity. Several studies have demonstrated the importance of the presence of nutrients as factors that favorably affect biodegradation (Steffensen and Alexander, 
Fig. 5 Percentage of diesel degradation in mangrove nonsterile sediments using bacterial consortium

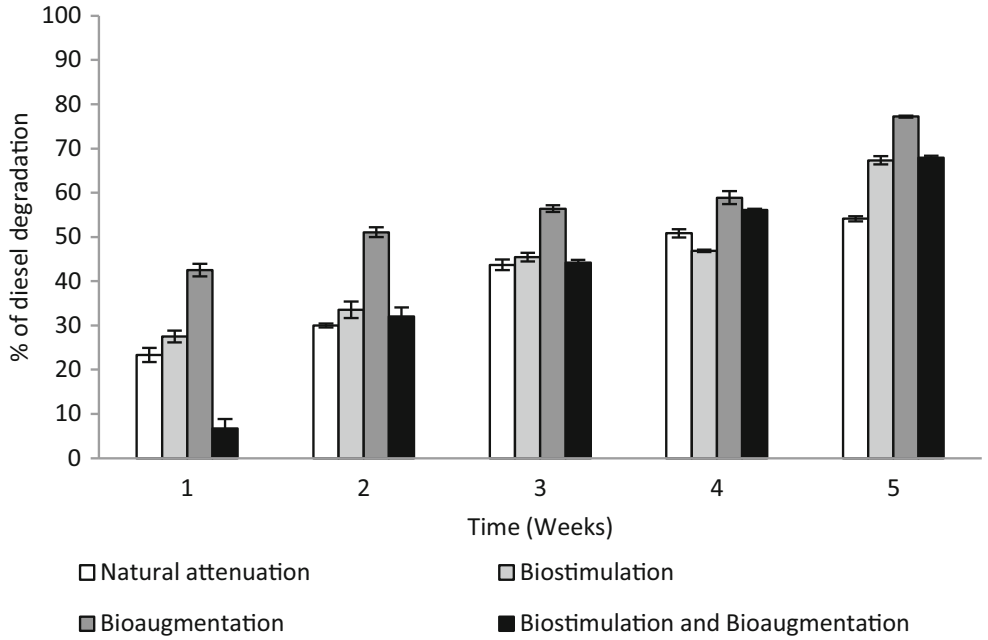

1995), and low levels of inorganic nutrients in the soil could affect or reduce the number of hydrocarbon-degrading bacteria (Chen et al., 2008). Nutrients have been suggested as one of the most important factors that accelerate PAH biodegradation and some inorganic nutrient concentrations in the soil could reduce the number of active bacteria at an inadequate level and slow down the biodegradation process (Steffensen and Alexander, 1995; Chen et al., 2008).

\subsection{Percentage of Diesel Degradation and Total Petroleum Hydrocarbon (TPH) in a Greenhouse}

Analysis of the results in terms of total hydrocarbon index shows a biodegradation activity in both microcosms containing sterile sediments compared to those containing non-sterile sediments. Thus, the ability of each microflora to degrade diesel will be appreciated according to the different treatments. This ability will also be assessed according to time in order to identify the treatment to be applied and with which bacteria in mangrove areas.

Figure 6 shows the results obtained in microcosms containing sediment sterile mangroves. The objective was to assess the capacity of diesel degradation by pure exogenous microorganisms such as $R$. erythropolis, $B$. subtilis, $P$. fluorescens and active bacterial consortium, which is part of the endogenous bacteria isolated from mangrove sediment. The first observation is that the degradation rate differs depending on the microorganism used. After 5 weeks of treatment, the rate of reduction of diesel was $91.1 \pm 1.7 \%$ in the microcosms treated with the bacterial consortium; this was $96.4 \pm 3 \%$ in the
Fig. 6 Percentage of diesel degradation by consortium in sterile mangrove sediments

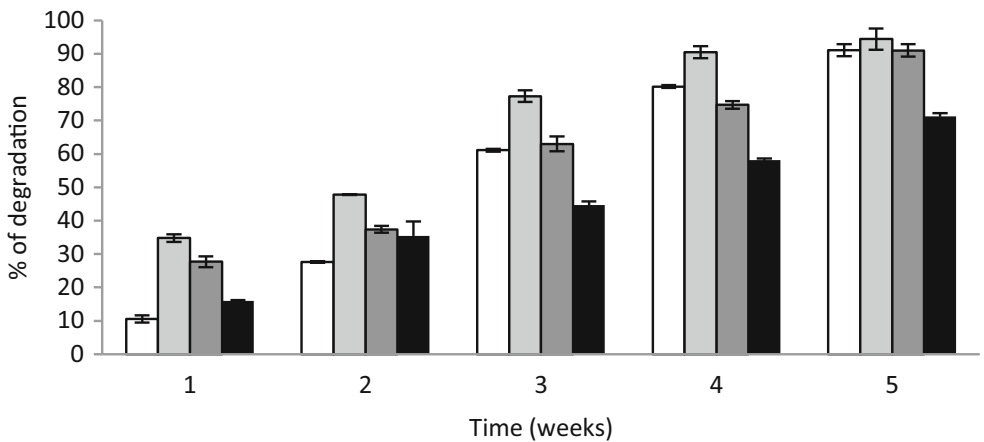

$\square$ Sterile sediments (Consortium)

$\square$ Sterile sediments (R. erythropolis)

$\square$ Sterile sediments (B. subtilis)
- Sterile sediments (P. fluorescens) 
microcosms treated with $R$. erythropolis, $91.0 \pm 1.9 \%$ for B. subtilis, and $71.2 \pm 0.9 \%$ for P. fluorescens. Statistical analysis shows that there is a significant difference between treatments. Similarly, there is a significant difference over time for the same treatment; that is to say, for two consecutive samples, there is a significant difference in the total petroleum hydrocarbon (TPH). In the analysis of these results, the first information we can draw is that the endogenous microflora and exogenous microflora present the capacity to degrade diesel. As the strains used are different from one another, the rate of degradation will also be different from one strain to another. $R$. erythropolis, compared with other inbred strains and endogenous bacterial consortia, has a better degradation rate of diesel.

Figure 7 shows degradation kinetics of diesel content in mangrove sediments from endogenous microflora. This experience highlights natural attenuation, biostimulation and bioaugmentation as treatments. Bioaugmentation is carried out with the addition of endogenous bacterial consortium, as an isolated asset, for its ability to metabolize diesel. Biostimulation is carried out by adding a mineral salt medium (MSM), compost or both to the microcosms. We also highlighted a combination of bioaugmentation and biostimulation; that is to say, the addition of the microcosms containing diesel, the endogenous bacterial consortium plus MSM, compost or both. After 5 weeks of treatment, the different degradation rates are estimated from the total petroleum hydrocarbon (TPH). Thus, the degradation rate observed for the natural attenuation processing is $29.1 \pm 1.2 \%$. It is $78.6 \pm 0.25 \%$ for bioaugmentation, $65.4 \pm 0.8 \%$ for biostimulation with the addition of MSM, 71.7.0 $\pm 0.4 \%$ for biostimulation with the addition of compost, and $79.8 \pm 1.5 \%$ for biostimulation with the addition of compost plus MSM. The combination of bioaugmentation and biostimulation with the addition of compost has a degradation rate of 86.2 $\pm 0.1 \%$, while this is $78.3 \pm 1.2 \%$ with the addition of the mineral salt solution. Statistical analysis of these results indicates that there is a significant difference for each treatment over time; that is to say, from one week to another, degradation rates are changed for the same treatment. Statistical analysis by one-way ANOVA with the Tukey comparison method (95\% confidence level) shows that taking reduction rate as a fixed variable compared to the treatment applied to each microcosm did not identify a significant difference between treatments.

The results in Fig. 8 are used to assess the capacity of endogenous microflora to degrade diesel. Experience shows treatment with a natural attenuation method, which requires the ability of endogenous microorganisms to metabolize diesel, treatment with a biostimulation method where some microcosms will have a mineral salt medium (MSM) added, or compost. This addition can boost the bacterial activity to optimize the

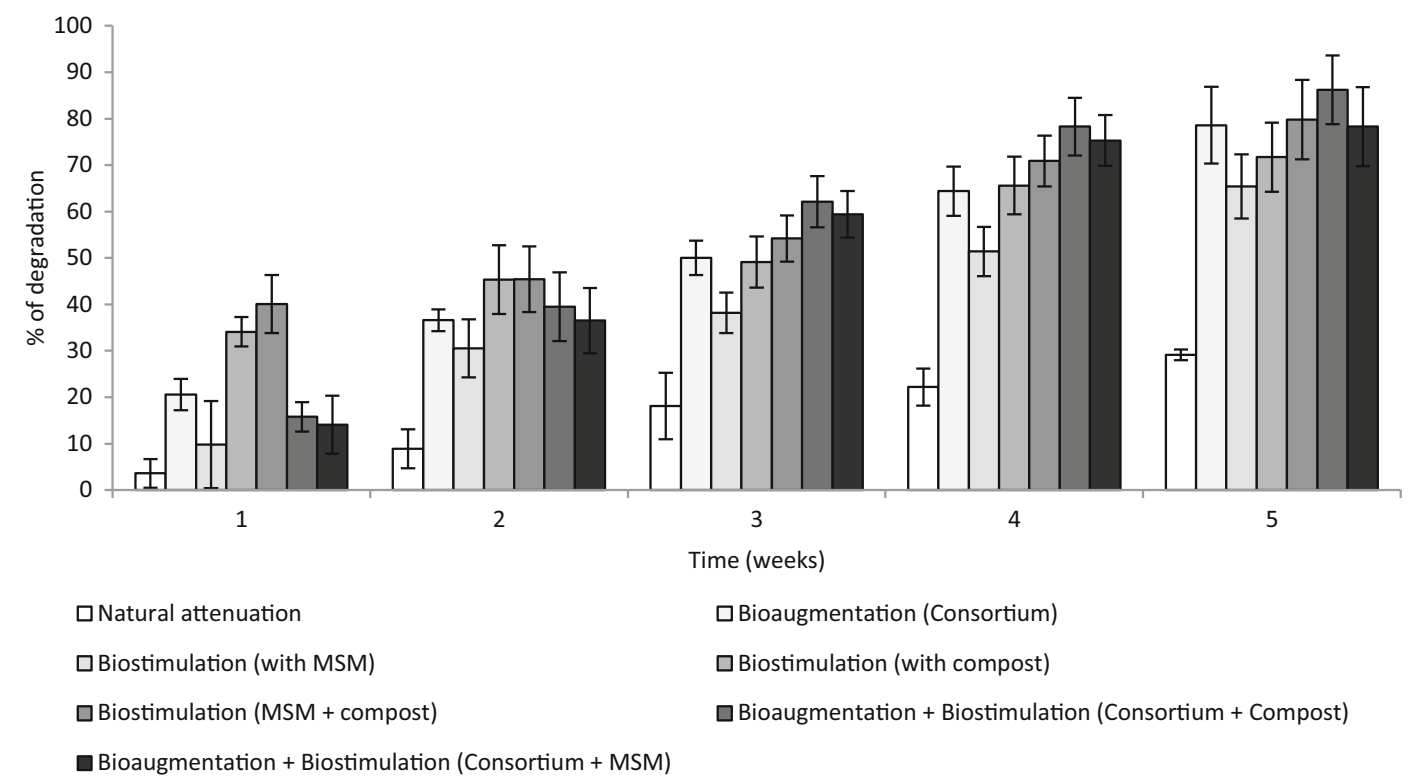

Fig. 7 Percentage of degradation of diesel by consortium using natural attenuation, bioaugmentation, and biostimulation methods 
Fig. 8 Percentage of degradation of diesel by endogenous bacterial using natural attenuation and biostimulation methods

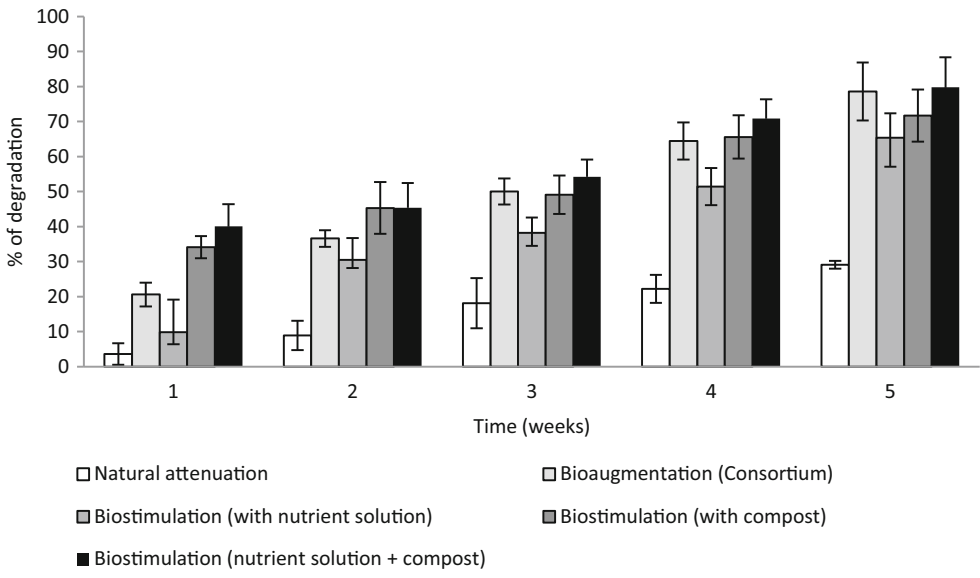

biodegradation process. It is clear that after 5 weeks of treatment, the diesel degradation rate by natural attenuation is quite low (about $30 \%$ ). It was therefore interesting to evaluate the potential impact of a mineral salt medium or compost or both on the performance of microorganisms. After 5 weeks of treatment, the degradation rate was $65.4 \pm 0.8 \%$ when MSM was added, $71.7 \pm 0.4 \%$ when compost was added, and $79.8 \pm 1.5 \%$ when MSM plus compost were added. MSM and compost are considered to bring nutrients and oxygen into the environment, which accelerates bacterial growth and promotes intense activity in the degradation of diesel. The results show a significant difference in degradation rate between the addition of MSM and the addition of the two components (MSM and compost), as well as a simple difference when comparing results with the addition of compost and adding the two compounds at the same time. Again, the difference was not significant when adding only the MSM and compost.

Assessment of the activity of endogenous microflora through the degradation of diesel gave a degradation rate of $29.1 \pm 1.2 \%$ after 5 weeks of treatment. This was the treatment by natural attenuation. Contrary to that which was observed in microcosms containing sterile sediments, the degradation was shown to be very slow and there was a low degradation rate at the same time. For this treatment by natural attenuation, we see from the results of the statistical analysis that the degradation rate is significantly different between the first and second week, and between the last 3 weeks. We could say that the endogenous microflora had a period of adjustment to the pollutant which was quite difficult; this adaptation increased over time. The low rate of active microflora in mangrove sediments $(10 \%$ of the total microflora) could give the first explanation of the slow degradation of diesel in these microcosms, as it would probably take longer for the proper adaptation of this microflora to pollutants.

The treatment with bioaugmentation was characterized by the addition of active endogenous or exogenous microflora, and presented more satisfactory results compared to natural attenuation. It should be noted that we used three exogenous pure strains, namely R. erythropolis, B. subtilis, and P. fluorescens, and isolated endogenous active consortium sediments of mangroves. The observation results in microcosms having undergone treatment with bioaugmentation, showing a difference in the diesel degradation rate based on the microorganisms used and the time taken to treat the sediment. In relative values, $R$. erythropolis had a higher degradation rate than $B$. subtilis, $P$. fluorescens and the endogenous consortium. Thus, after 5 weeks of treatment, there was a degradation rate of $84.8 \pm 2.6 \%$ in the microcosms treated with $R$. erythropolis, a degradation rate of $78.6 \pm 1.2 \%$ in the microcosms treated with the consortium, a $69.4 \pm 2.9 \%$ rate of degradation in the microcosms treated with $B$. subtilis, and finally a degradation rate of $61.7 \pm 0.4 \%$ in the microcosms treated with $P$. fluorescens (Fig. 6). Statistically, a difference was observed between treatment with $R$. erythropolis and two treatments with the consortium and B. subtilis. In contrast, there is a significant difference in treatment with $R$. erythropolis and treatment with $P$. fluorescens. However, the different degradation rates observed for each treatment are significantly different from one week to another; that is to say, over time, there is a significant difference between two samples for the same treatment. Probably in one case as in the other, increasing the active 
microflora $\left(+10^{7} \mathrm{CFU} / \mathrm{g}\right.$ dry matter) accelerated the diesel degradation. The three pure strains used here are well-known for their ability to degrade hydrocarbons alone or in combination with other bacteria. According to Liu (2011), R. erythropolis has oxygenases that make them capable of degrading oil components such as nalkanes, iso-alkanes, cycloalkanes, and aromatics.

In this experiment, we used a technique that combines both bioaugmentation and biostimulation methods. Bioaugmentation was performed by the addition of different bacterial strains such as $P$. fluorescens, $B$. subtilis, $R$. erythropolis and the isolated bacterial consortium mangrove sediments. Biostimulation is achieved by adding to each microcosm series compost or mineral salt medium. From the observation of results, after 5 weeks of treatment, in microcosms containing compost, there was a diesel reduction rate of 80.8 $\pm 0.2 \%$ in the microcosms treated with $P$. fluorescens, $86.2 \pm 0.1 \%$ with the endogenous consortium 86.7 $\pm 0.07 \%$ with $B$. subtilis and $92.0 \pm 0.02 \%$ with
R. erythropolis (Fig. 9). Statistical analysis of these results reveals that there is no significant difference between treatments. However, there is a significant difference over time during the first three weeks. There is no significant difference in the degradation of diesel in the last two weeks, irrespective of the treatment. The general compost acts as a biostimulant, providing nutrients to the existing microflora; it also improves sediment structure by promoting soil aeration through the various elements. The mineral-salt medium is used in the same proportions in each microcosm; the degradation rate observed here is the exclusive result of bacterial activity. $R$. erythropolis appears to be the most appropriate strain for the degradation of diesel over time. In order 77.5 $\pm 0.2 \%$ is noted as diesel degradation rates in microcosms containing $P$. fluorescens, $78.3 \pm 1.2 \%$ in microcosms containing endogenous consortium, 84.4 $\pm 0.07 \%$ with $B$. subtilis, and $90.6 \pm 0.08 \%$ with $R$. erythropolis. As in the previous case with compost, the statistical analysis of these results reveals that there
Fig. 9 Percentage of diesel degradation using two methods combined: biostimulation and bioaugmentation

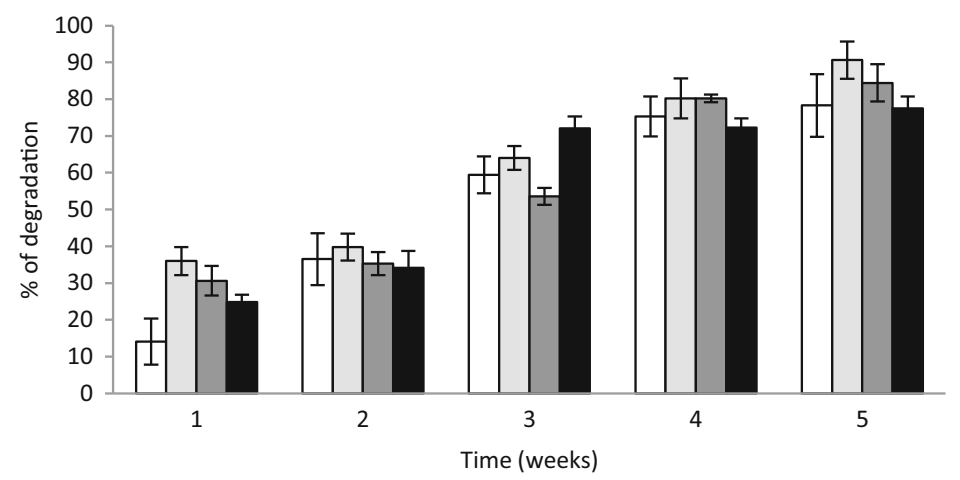

$\begin{array}{ll}\square \text { Consortium and nutrient solution } & \square \text { R. erythropolis and nutrient solution } \\ \square \text { B. subtilis and nutrient solution } & \square \text { P. fluorescens and nutrient solution }\end{array}$

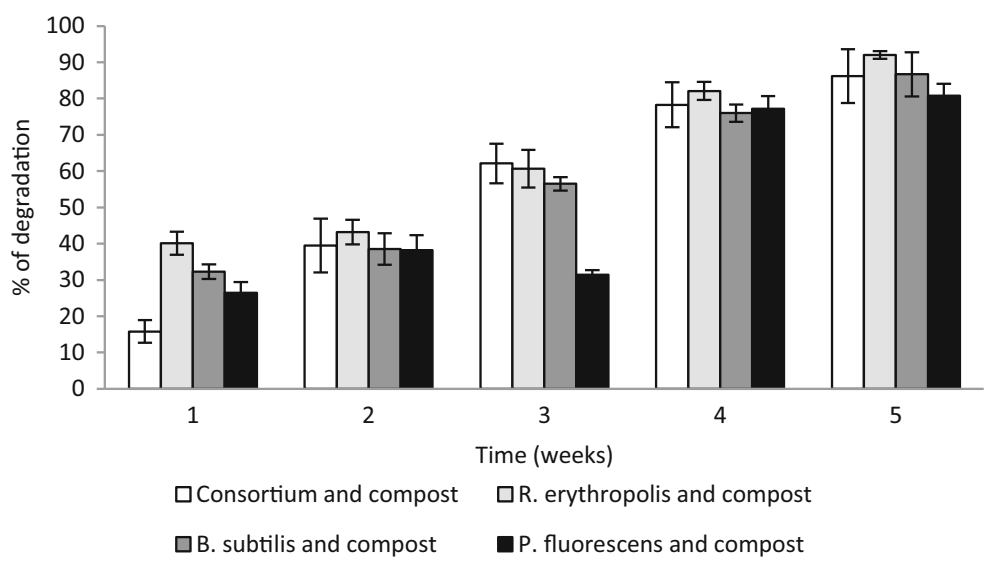


is no significant difference between treatments. There is a significant difference over time during the first 3 weeks. There is no significant difference in the degradation of diesel in the last 2 weeks, irrespective of the treatment.

Biodegradation is dependent on several factors including the oxygen concentration of the environment, environmental temperature, $\mathrm{pH}$ and the presence of nutrients in the medium. Microorganisms require appropriate environmental conditions to successfully reduce, eliminate, or transform contaminants present in different media (Fulekar, 2010; Ghaly et al., 2013). Under these conditions, successfully degraded molecules are natural organic compounds such as light hydrocarbons such as diesel (Bulman and Newland 1993; Bragg et al., 1994; Wenderoth et al., 2003). Compared to natural attenuation, the analysis of samples by flow cytometry showed cell viability of $63 \%$ and $70 \%$, respectively, for the first and second week of treatment. The results obtained from the bioaugmentation treatment are quite satisfactory and are better than those obtained by biostimulation. It should be noted that the rate of degradation here is a function of the bacterial strain used. $R$. erythropolis strain has better degradation compared to B. subtilis, $P$. fluorescens, and the consortium. Combining bioaugmentation and biostimulation, we obtained even better results. The increase in bacteria $\left(10^{7} \mathrm{CFU} / \mathrm{g}\right.$ of dry matter) and the improvement of environmental conditions (medium temperature between 27 and $30{ }^{\circ} \mathrm{C}$ ) promoted better diesel degradation kinetics compared to all other strategies in place. $R$. erythropolis always presented better results than other species. By focusing more on this strain, the literature indicates that the genus Rhodococcus is a very diverse group of bacteria that possesses the ability to degrade a large number of organic compounds, including some of the most difficult compounds with regard to recalcitrance and toxicity (Larkin et al., 2005). Rhodococcus can catabolize short and long-chain alkanes, aromatic (halogenated and nitro-substituted), heterocyclic, and polycyclic aromatic compounds. According to Liu (2011), these strains possess oxygenases, making them capable to biodegrade the constituents of petroleum such as n-alkanes, isoalkanes, cycloalkanes, and aromatic compounds (Atlas, 1981; Hamamura et al., 2008). For example, $R$. erythropolis was able to use 20,000 ppmv of crude oil as the only energy source (Karpenko et al., 2006) demonstrating the potential of Rhodococcus strains to bioremediation. The success of members of the genus Rhodococcus in degrading aromatic compounds is based upon the possession of a wide range of dioxygenases (Larkin et al., 2005).

Five weeks after the experiment, the results showed a high concentration in diesel in control sediment in sterile flasks and in the greenhouse. Only a small fraction was eliminated. The results show that $3.5 \%$ and $7.6 \%$ diesel have evaporated sterile control sediment respectively flask and microcosms (Table 3). Sediments are sterilized by autoclave. This sterilization allows taking out the total microflora. This loss of diesel is certainly due to volatilization by evaporation of diesel. The degradation of diesel was effective in sterile sediment when microorganisms were added into the material. Thus, the microorganisms used in our experiment were able to degrade diesel.

To degrade diesel found in mangrove sediments we have worked with, we controlled two main elements. Both elements can be limiting factors for biodegradation. Temperature was adjusted at $30{ }^{\circ} \mathrm{C}$, and we focused on the contribution of microorganisms and the presence of nutrients. The first part of the experiment consisted in demonstrating the presence of

Table 3 Mass balance of diesel, amount remained ( $\mathrm{ppm}$ ) and percentages of total hydrocarbons (input) in sterile control sediments after 5 weeks

\begin{tabular}{lllll}
\hline Hydrocarbon & Fate of hydrocarbon & In flasks & & In greenhouse \\
& & Sterile control & & Sterile control \\
\cline { 3 - 5 } & & Amounts (ppm) & Input (\%) & Amounts (ppm) \\
\hline Diesel & Input & $14,900 \pm 82.3$ & & $21,000 \pm 2778$ \\
& In sediment & $14,383 \pm 237$ & 96.5 & $19,405 \pm 1824$ \\
& Losses & 517 & 3.4 & $1595 \pm 924$ \\
\hline
\end{tabular}


Fig. 10 Percentage of biodegradation of diesel using natural attenuation and bioaugmentation methods

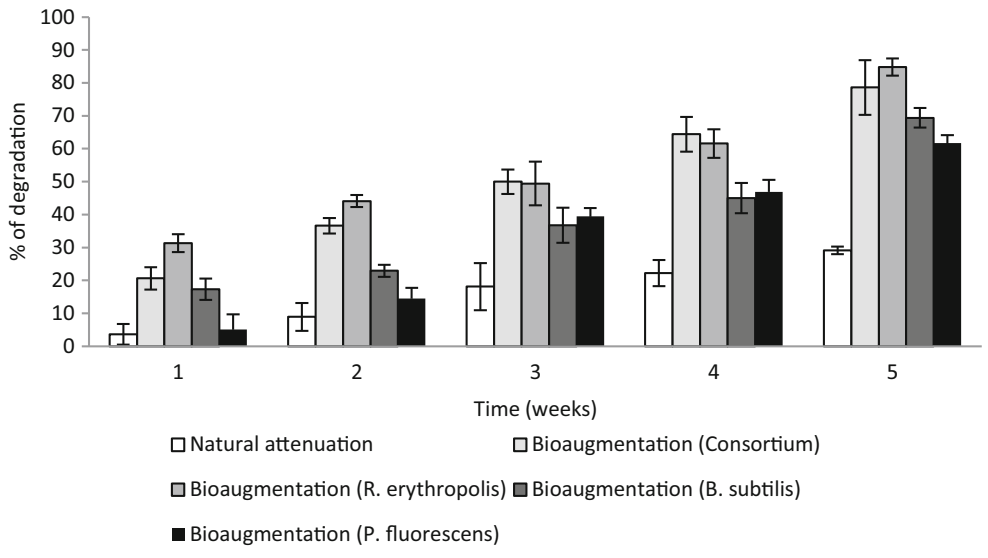

microorganisms able to degrade diesel. Then, we used an isolated mangrove sediment consortium able to degrade hydrocarbons. As it was suggested by Venosa et al., (2002), the presence of microorganisms with the appropriate metabolic abilities is the most important requirement for bioremediation. Several studies of the biodegradation of hydrocarbons in mangrove ecosystems have already used endogenous and/or exogenous consortia or pure strains (Bento et al., 2005; Yu et al.,
2005; Chen et al., 2008; Liu and Liu 2011). In all treatments performed (natural attenuation, biostimulation and bioaugmentation), the presence of microorganisms able to degrade diesel has been reported. The second parameter to be studied is the presence of nutrients. Some nutrients such as nitrogen and phosphorus are essential for growth and metabolic activities of microorganisms. In the treatment by biostimulation, we added a mineral solution containing nitrogen and
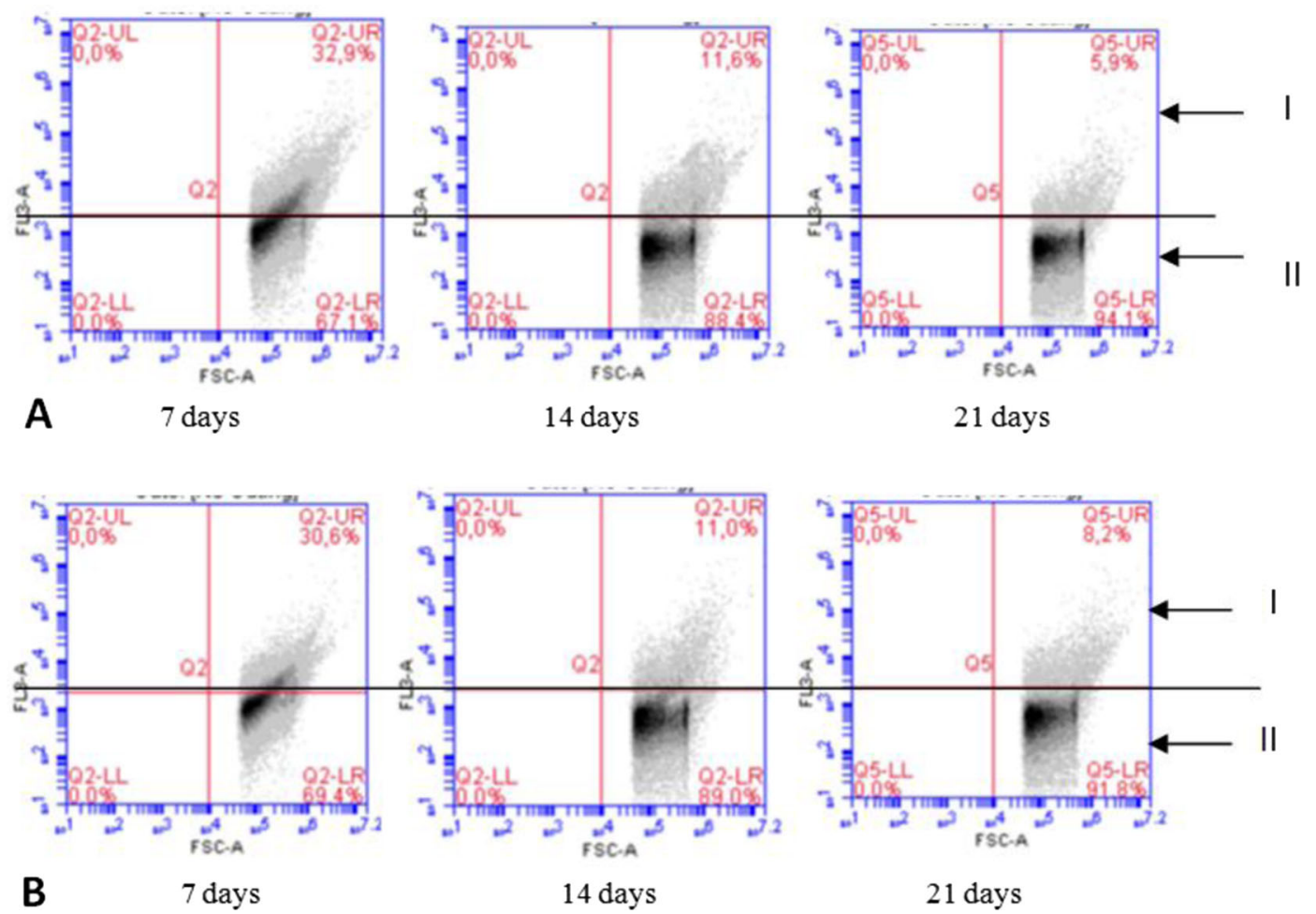

Fig. 11 Cytograms presenting evolution of microorganisms in mangrove sterile sediment over 21 days. a sterile sediments + consortium, $\mathbf{b}$ sterile sediments + consortium + nutrient solution 
phosphorus. Biostimulation is the addition of limiting nutrients to support microbial growth. According to Adams et al., (2015) bioremediation uses microbial metabolism in the presence of optimal environmental conditions and sufficient nutrients to breakdown contaminants, notably petroleum hydrocarbons. Microorganisms able to degrade petroleum products are known to use directly metabolizable nitrogen and phosphorus compounds as helping agents for biodegradation. The fertilizer supply causes an increase in heterotrophic and hydrocarbon-splitting bacteria and an increase in the phytoplanktonic biomass (LePetit and N'Guyen 1976). The various degradation rates obtained in flasks and the greenhouse in this experiment are comparable in time to those that are found in the literature. Using the compost to make his experiment of biostimulation, Atagana (2008) obtained $100 \%$ of degradation after 570 days of treatment. After 84 days, Abioye et al., (2012) obtained $92 \%$ of degradation of TPH by biostimulation and $55 \%$ by natural attenuation. Also using organic nutrients, Chikere (2012) obtained in two different experiments $95 \%$ and $98 \%$ of degradation after 56 days. Orji et al. (2012) obtained $63 \%$ of degradation by treating sludge mangroves by biostimulation with organic nutrients. As for the degradation of diesel by bioaugmentation, Fan et al. (2013) obtained $83 \%$ TPH removal using an exogenous pure strain and $61 \%$ using indigenous microorganisms. Wu et al. (2012) obtained more than $60 \%$ after 270 days using $P$. fluorescens. All these different reduction rates are comparable to our results. The main difference is the short time of this study.

\subsection{Characterization of the Consortium by Flow} Cytometry in Flasks Experiment

The evolution of the consortium during 21 days in flasks in sterile and non-sterile sediments was observed by the flow cytometry method. Interpretation of the results was performed using the PI coloration of cells, as cells that stain with PI are either dead or have poor membrane integrity. PI penetrates the cell membrane and binds to the DNA. The uncolored cells are alive and show good membrane integrity. The cytograms of the consortium in flasks show two subpopulations: a subpopulation (I) containing the PI-labeled cells and a subpopulation (II) containing intact cells that resist the effects of diesel and are not labeled with PI. The results during the 21 days of experiment are presented in Figs. 8 and 10 for sterile and non-sterile conditions, respectively.

The cytograms presented in Fig. 8 are those of the flasks containing sterile sediments. After 7 days of treatment, the subpopulation with poor membrane integrity represented $33 \%$ in the treatment where nutrient solution only was added, compared to $30 \%$ in the flasks with consortium and nutrient solution added. These percentages dropped to 11 and $11 \%$, respectively, after 14 days of treatment to finally reach 6 and $8 \%$, respectively, after 21 days of treatment. This decrease in subpopulation (I) can be explained by the fact that diesel degraded in the sediment over time. After 21 days, the degradation rate was $46 \%$ in the flasks with only the consortium added and $31 \%$ in the flasks with the consortium and nutrient solution added. This reduced the stress induced by the pollutant in the cells. Moreover, the consortium probably became acclimated to diesel and metabolized it over time (Wild and Jones, 1986; Chaneau et al., 1999; Zhang et al., 2006).

In the other treatments performed with non-sterile sediment, the trend was the same. Analysis of cytograms in both cases shows a progressive adaptation of endogenous microflora to stress caused by the diesel during treatment. This adaptation is based on the degradation of the pollutant in the flasks. This leads us to conclude that the consortium was probably acclimated to diesel and metabolized it over time.

The cytograms in Figs. 11 and 12 show that diesel has a negative effect on membrane integrity or survival of microorganisms with PI staining at the cell membrane. This negative effect is higher in the first week of the experiment. Thereafter, it is found that the percentage of microorganisms undergoing PI staining in their membrane decreases with time. This could be explained by the fact that microorganisms adapt gradually to diesel. The addition of nutrients does not reduce this negative effect of diesel but seems to increase the size and metabolic activity of bacterial strains. The consortium in sterile flasks becomes colored at least PI microorganisms compared to non-sterile flasks. This is due to the fact that the consortium undergoes less stress and is well-adapted to diesel.

\section{Conclusion}

The results obtained in this study must take account of the fact that diesel was manually added into the samples. 

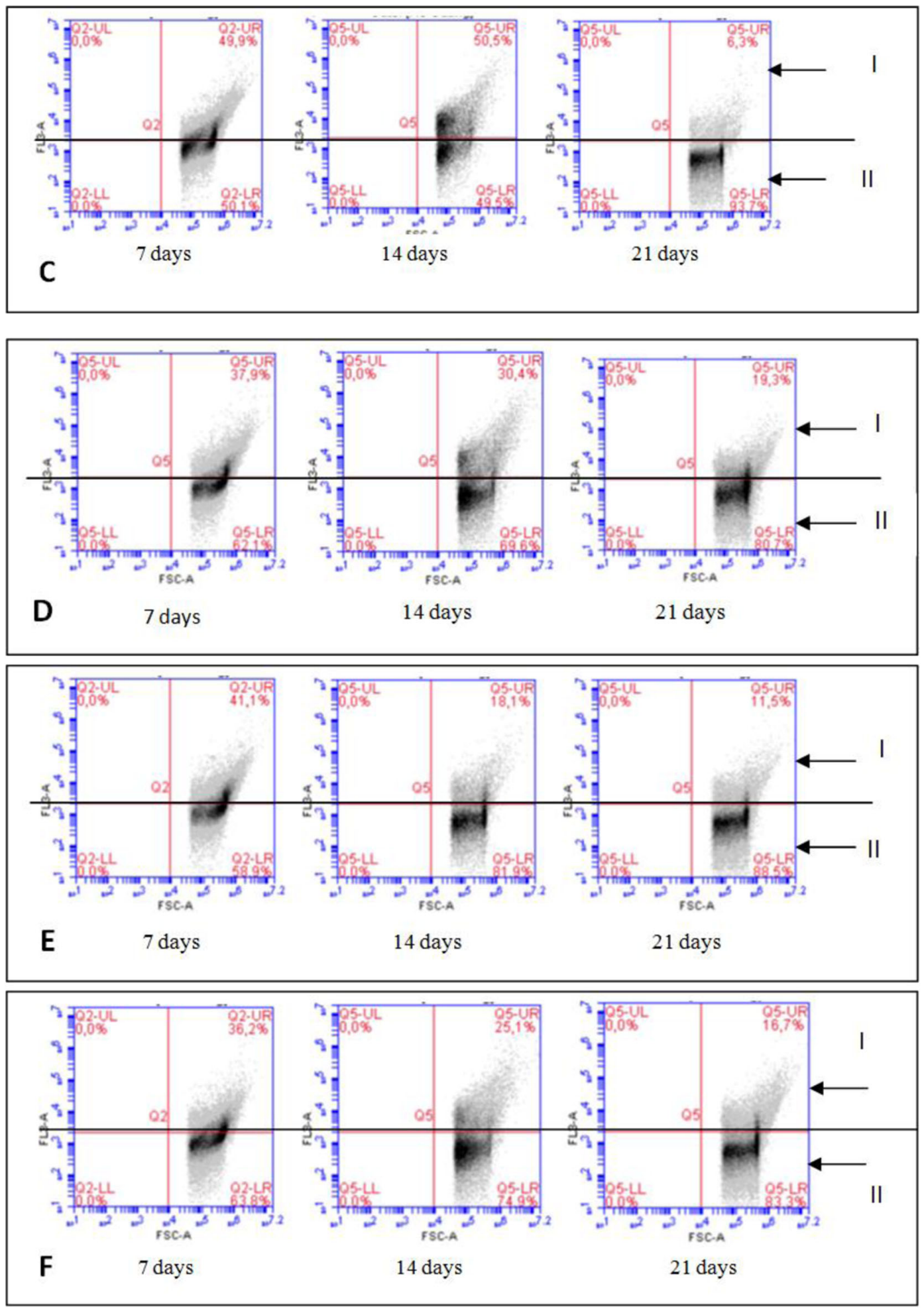

Fig. 12 Cytograms presenting evolution of microorganisms in mangrove non-sterile sediments. c cytograms of samples treated by natural attenuation, d cytograms of samples treated by biostimulation, e cytograms of samples treated by bioaugmentation, and $\mathbf{f}$ cytograms of samples treated both by biostimulation and bioaugmentation 
The results of this study show that, in the first step, mangrove sediment contains an active microflora that can metabolize diesel. Indigenous and active microflora presents an interesting potential for diesel degradation. Our consortium adapted well to various conditions and was resistant to pollutant-induced stress. Nutrient supplementation significantly increased the rate of diesel degradation (90\% after 35 days). In general, we found that the consortium adapts well to the pollutant; the degradation of diesel is the consequence of this adaptation. In the second step, different treatments on mangrove sediments artificially polluted by diesel such as natural attenuation, biostimulation and bioaugmentation showed the ability of endogenous microflora to degrade diesel. However, the degradation rates obtained with the endogenous microflora in relation to the time or duration of the treatment were substantially lower than those obtained when the treatment was carried out with the addition of exogenous bacteria for the same duration. Bioaugmentation with the addition of Rhodococcus erythropolis presented good results in this case. These results were even better when the treatment was a combination of bioaugmentation and biostimulation.

\section{References}

Abioye, O. P., Agamuthu, P., \& Abdul-Aziz, R. A. (2012). Biodegradation of used motor oil using organic waste amendment. Biotechnology Research International. doi:10.1155/ 2012/587041Research.

Adams, G. O., Fufeyin, P. T., Okoro, S. E., Ehinomen, I. (2015). Bioremediation, Biostimulation and Bioaugmention: A Review. International Journal of Environmental Bioremediation \& Biodegradation, 3(1), 28-39.

Alongi, D. M. (1988). Bacterial productivity and microbial biomass in tropical mangrove sediments. Microbiology Ecology, $15,59-79$.

Atagana, H. I. (2008). Compost bioremediation of hydrocarboncontaminated soil inoculated with organic manure. African Journal of Biotechnology, 7(10), 1516-1525.

Atlas, R. M., \& Bragg, J. (2009). Bioremediation of marine oil spills: when and when not-the Exxon Valdez experience. Microbial Biotechnology, 2(2), 213-221.

Atlas, R. M. (1981). Microbial-degradation of petroleum-hydrocarbons - an environmental perspective. Microbiological Reviews, 45(1), 180-209.

Barathi, S., \& Vasudevan, N. (2001). Utilization of petroleum hydrocarbons by Pseudomonas fluorescens isolated from a petroleum-contaminated soil. Environmental International, 26(5-6), 413-416.

Bartha, R., \& Bossert, I. (1984). The treatment and disposal of petroleum wastes. In Petroleum Microbiology (Ed.), R. M. Atlas (pp. 553-578). Macmillan: New York, USA.
Bento, F. M., Camargo, F. A. O., Okeke, B. C., Frankenberger, W. T. (2005). Comparative bioremediation of soils contaminated with diesel oil by natural attenuation, biostimulation and bioaugmentation. Bioresource Technology, 96, 1049-1055.

Bernard, D., Pascaline, H., Jeremie, J. J. (1996). Distribution and origin of hydrocarbons in sediments from lagoons with fringing mangrove communities. Marine Pollution Bulletin, 32, 734-739.

Bicca, F. C., Fleck, L. C., \& Ayub, M. A. Z. (1999). Production of biosurfactant by hydrocarbon degrading Rhodococcus ruber and Rhodococcus erythropolis. Revista de Microbiologia, 30, 231-236.

Bragg, J. R., Prince, R. C., Harner, E. J., \& Atlas, R. M. (1994). Effectiveness of bioremediation for the Exxon Valdez oil spill. Nature, 368, 413-418.

Brandao, P. F., Clapp, J. P., \& Bull, A. T. (2003). Diversity of nitrile hydratase and amidase enzyme genes in Rhodococcus erythropolis recovered from geographically distinct habitats. Applied and Environmental Microbiology, 69, 5754-5766.

Brito, E. M. S., Guyoneaud, R., Goñi-Urriza, M., Ranchou-Peyruse, A., Verbaere, A., Crapez, M. A. C., Wasserman, J. C. A., \& Duran, R. (2006). Characterization of hydrocarbonoclastic bacterial communities from mangrove sediments in Guanabara Bay, Brazil. Research in Microbiology, 157, 752-762.

Brooijmans, R. J. W., Pastink, M. I., \& Siezen, R. J. (2009). Hydrocarbon-degrading bacteria: the oil-spill clean-up crew. Microbial Biotechnology, 2(6), 587-594.

Bulman, T. L., \& Newland, M. (1993). In situ bioventing of a diesel fuel spill. Hydrological Sciences Journal, 8, 297-308.

Chandrasekhar, N., \& Karigar, C. S. (2010). Bacterial degradation of anthracene by pseudomonas fluorescens KCP2. Asian Journal of Microbiology, Biotechnology \& Environmental Sciences, 12(3), 591-597.

Chaneau, C. H., Morel, J., Dupont, J., Bury, E., \& Oudot, J. (1999). Comparison of the fuel oil biodegradation potential of hydrocarbon-assimilating microorganisms isolated from a temperate agricultural soil. Science of the Total Environment, 227, 237-247.

Chen, J., Wong, M. H., Wong, Y. S., \& Tam, N. F. Y. (2008). Multi-factors on biodegradation kinetics of polycyclic aromatic hydrocarbons (PAHs) by Sphingomonas sp. a bacterial strain isolated from mangrove sediment. Marine Pollution Bulletin, 57, 695-702.

Chikere, C. B. (2012). Culture-independent analysis of bacterial community composition during bioremediation of crude oilpolluted soil. British Microbiology Research Journal, 2(3), 187-211.

Christova, N., Tulevaa, B., \& Nikolova-Damyanova, B. (2004). Enhanced hydrocarbon biodegradation by a newly isolated Bacillus subtilis strain. Zeitschrift für Naturforschung, 59c, 205-208.

Colwell, R. R., Walker, J. D., \& Cooney, J. J. (1977). Ecological aspects of microbial degradation of petroleum in the marine environment. Critical Reviews in Microbiology, 5(4), 423-445.

Cooney, J. J., Silver, S. A., \& Beck, E. A. (1985). Factors influencing hydrocarbon degradation in three freshwater lakes. Microbial Ecology, 11(2), 127-137.

Darsa, K. V., Thatheyus, A. J., \& Ramya, D. (2014). Biodegradation of petroleum compound using the bacterium Bacillus subtilis. Science International, 2(1), 20-25. 
Das, K., \& Mukherjee, A. K. (2007). Crude petroleum-oil biodegradation efficiency of Bacillus subtilis and Pseudomonas aeruginosa strains isolated from a petroleum-oil contaminated soil from North-East India. Bioresource Technology, 98(7), 1339-1345.

Ellis, R. J., Morgan, P., Weightman, A. J., \& Fry, J. C. (2003). Cultivation-dependant and independent approaches for determining bacterial diversity in heavy metal contaminated soil. Applied and Environmental Microbiology, 69, 3223-3230.

Fan, M. Y., Xie, R. J., \& Qin, G. (2013). Bioremediation of petroleum-contaminated soil by a combined system of biostimulation-bioaugmentation with yeast. Environmental Technology, 35, 4.

Floodgate, G. (1984). The fate of petroleum in marine ecosystems. In P. Microbiology (Ed.), R. M. Atlas (pp. 355-398). Macmillan: New York, USA.

Fulekar, M. H. (2010). Global status of environmental pollution and its remediation. In Fulekar M. H. (Eds.), Recent Advances. Bioremediation Technology, 1-6.

Ghaly A. E., Yusran A., Dave D. (2013). Effects of biostimulation and bioaugmentation on the degradation of pyrene in soil. Journal Bioremediation Biodegradation, 5, 1-13.

Hamamura, N., Fukui, M., Ward, D. M., \& Inskeep, W. P. (2008). Assessing soil microbial populations responding to crude-oil amendment at different temperatures using phylogenetic, functional gene (alkB) and physiological analyses. Environmental Science and Technology, 42, 7580-7586.

Holguin, G., Vazquez, P., \& Bashan, Y. (2001). The role of sediment microorganisms in the productivity, conservation, and rehabilitation of mangrove ecosystems: an overview. Biology and Fertility of Soils, 33, 265-278.

Jalilzadeh Yengejeh, R., Sekhavatjou, M. S., Maktabi, P., Arbab Soleimani, N., Khadivi, S., \& Pourjafarian, V. (2014). The biodegradation of crude oil by Bacillus subtilis isolated from contaminated soil in hot weather areas. International Journal of Environmental Research, 8(2), 509-514.

Kaczorek, E., \& Olszanowski, A. (2011). Uptake of hydrocarbon by Pseudomonas fluorescens (P1) and Pseudomonas putida (K1) strains in the presence of surfactants: a cell surface modification. Water, Air, and Soil Pollution, 214, 451-459.

Karpenko, E. V., Vil'danova-Martsishin, R. I., Shcheglova, N. S., Pirog, T. P., \& Voloshina, I. N. (2006). The prospects of using bacteria of the genus Rhodococcus and microbial surfactants for the degradation of oil pollutants. Applied Biochemistry and Microbiology, 42, 156-159.

Khan, M., \& Scullion, J. (2002). Effects of metal (Cd, Cu, Ni, Pb or $\mathrm{Zn}$ ) enrichment of sewage-sludge on soil micro-organisms and their activities. Applied Soil Ecology, 20, 145-155.

Larkin, M. J., Kulakov, L. A., \& Allen, C. C. R. (2005). Biodegradation and Rhodococcus - masters of catabolic versatility. Environmental Biotechnology, 16, 282-290.

Leahy, J. G., \& Colwell, R. R. (1990). Microbial degradation of hydrocarbons in the environment. Microbiological Reviews, 5, 305-315.

LePetit, J., \& N'Guyen, M.-H. (1976). Besoins en phosphore des bacteries metabolisant les hydrocarbures en mer. Canadian Journal of Microbiology, 22, 1364-1373.

Lu, H., Zhang, Y., Liu, B., Liu, J., Ye, J., \& Yan, C. (2011). Rhizodegradation gradients of phenanthrene and pyrene in sediment of mangrove (Kandelia candel (L.) Druce). Journal of Hazardous Materials, 196, 263-269.

Liu, C. W., \& Liu, H. S. (2011). Rhodococcus erythropolis strain NTU-1 efficiently degrades and traps diesel and crude oil in batch and fed-batch bioreactors. Process Biochemistry, 46, 202-209.

Mehdi, F. S., Siddiqu, I. A., Ali, N. I., \& Afzal, M. (2000). Rhizosphere mycoflora of black mangrove seedling at Karachi coast. Pakistan Journal of Biological Sciences, 3(8), 1352-1353.

Moran, A. C., Olivera, N., Commendatore, M., Esteves, J. L., \& Sineriz, F. (2000). Enhancement of hydrocarbon waste biodegradation by addition of a biosurfactant from Bacillus subtilis O9. Biodegradation, 11, 65-71.

Moreira, I. T. A., Oliveira, O. M. C., Triguis, J. A., Dos Santos, A. M. P., Queiroz, A. F. S., Martins, C. M. S., Silva, C. S., \& Jesus, R. S. (2011). Phytoremediation using Rhizophora mangle L. in mangrove sediments contaminated by persistent total petroleum hydrocarbons (TPH's). Microchemical Journal, 29, 376-382.

Orji, F. A., Abiye, A. I., \& Dike, E. N. (2012). Laboratory scale bioremediation of petroleum hydrocarbon-polluted mangrove swamps in the Niger Delta using cow dung. Malaysian Journal of Microbiology, 8(4), 219-228.

Owens, E. H., Solsberg, L. B., West, M. R., \& McGrath, M. (1998). Field guide for oil spill response in arctic waters (Emergency prevention, preparedness and response (EPPR), p. 348). Yellowknife, NT Canada: Environment Canada.

Perry, J. J. (1984). Microbial metabolism of cyclic alkanes. In Petroleum Microbiology (Ed.), R. M. Atlas (pp. 61-98). New York, USA: Macmillan.

Queiroga, C. L., Nascimento, L. R., \& Serra, G. E. (2003). Evaluation of paraffin biodegradation and biosurfactant production by Bacillus subtilis in the presence of crude oil. Brazilian Journal of Microbiology, 34(4), 321-324.

Rahman, K. S. M., Rahman, T. J., Kourkoutas, Y., Petsas, I., Marchant, R., \& Banat, I. M. (2003). Enhanced bioremediation of n-alkane in petroleum sludge using bacterial consortium amended with rhamnolipid and micronutrients. Bioprocess Technology, 90(2), 159-168.

Ramsay, M. A., Swannell, R. P. J., Shipton, W. A., Duke, N. C., Hill, R. T. (2000). Effect of bioremediation on the microbial community in oiled mangrove sediments. Marine Pollution Bulletin, 41(12), 413-419.

Singh, A., Kumar, V., \& Shrivastava, J. N. (2010). Green biotechnology of EM in bioremediation of wastewater. Geobios, 37, 231-237.

Steffensen, W. S., \& Alexander, M. (1995). Role of competition for inorganic nutrients in the biodegradation of mixtures of substrates. Applied and Environmental Microbiology, 61, 2859-2862.

Tam, N. F. Y., \& Wong, Y. S. (2008). Effectiveness of bacterial inoculum and mangrove plants on remediation of sediment contaminated with polycyclic aromatic hydrocarbons. Marine Pollution Bulletin, 57, 716-726.

Tam, N. F. Y., Guo, C. L., Yau, W. Y., \& Wong, Y. S. (2002). Preliminary study on biodegradation of phenanthrene by bacteria isolated from mangrove sediments in Hong Kong. Marine Pollution Bulletin, 42, 316-324.

Tian, Y., Liu, H. J., Zheng, T. L., Kwon, K. K., Kim, S. J., Yan, C. L. (2008). PAHs contamination and bacterial communities in 
mangrove surface sediments of the Jiulong River Estuary, China. Marine Pollution Bulletin, 57, 707-715.

Ulrici, W. (2000). Contaminant soil areas, different countries and contaminant monitoring of contaminants. In: H.J. Rehm and G. Reed (Eds.), Environmental Process II. Soil Decontamination Biotechnology, 11, 5-42.

Venosa, A.D., Lee, K., Suidan, M.T., Garcia-Blanco, S., Cobanli, S., Moteleb, M., Haines, J.R., Tremblay, G., \& Hazelwood, M. (2002). Bioremediation and biorestoration of a crude oil contaminated freshwater wetland on the St. Lawrence River. Bioremediation Journal, 6(3), 261-281.

Wang, Q., Zhang, S., Li, Y., \& Klassen, W. (2011). Potential approaches to improving biodegradation of hydrocarbons for bioremediation of crude oil pollution. Journal of Environmental Protection, 2, 47-55.

Wenderoth, D. F., Rosenbrock, P., Abraham, W. R., Pieper, D. H., \& Höfle, M. G. (2003). Bacterial community dynamics during biostimulation and bioaugmentation experiments aiming at chlorobenzene degradation in groundwater. Microbial Ecology, 46, 161-176.

Wild, S. R., \& Jones, K. C. (1986). Biological and abiotic losses of polynuclear hydrocarbons from soils freshly amended with sewage sludge. Environmental Toxicology and Chemistry, $12,5-12$.

Wu, T., Xie, W. J., Yi, L., Li, X. B., Yang, B. H., \& Wang, J. (2012). Surface activity of salt-tolerant Serratia spp. and crude oil biodegradation in saline soil. Plant, Soil and Environment, 58(9), 412-416.

Yakimov, M. M., Timmis, K. N., \& Golyshin, P. N. (2007). Obligate oil-degrading marine bacteria. Current Opinion in Biotechnology, 18(3), 257-266.

Yu, S. H., Ke, L., Wong, Y. S., \& Tam, N. F. Y. (2005). Degradation of polycyclic aromatic hydrocarbons (PAHS) by a bacterial consortium enriched from mangrove sediments. Environment International, 31, 149-154.

Zhang, X., Kimmel, M. R. D., McGilliard, C., \& Boicourt, W. (2006). Spatial variability in plankton biomass and hydrographic variables along an axial transect in Chesapeake Bay. Journal of Geophysical Research, Oceans, 111(5), 1978-2012.

Zhang, C. G., Leung, K. K., Wong, Y. S., \& Tam, N. F. Y. (2007). Germination, growth and physiological responses of mangrove plant (Bruguiera gymnorrhiza) to lubricating oil pollution. Environmental and Experimental Botany, 60, 127-136. 